\title{
Congressional Authority to Restrict Lower Federal Court Jurisdiction
}

\author{
Theodore Eisenbergt
}

Separation of powers in the federal government inevitably generates conflicts among the branches. In recent years the executive branch's authority to impound funds appropriated by Congress ${ }^{1}$ and to make war without congressional approval ${ }^{2}$ has been questioned. In earlier days debate raged over the Supreme Court's authority to nullify legislation passed by Congress. ${ }^{3}$ A recurrent example of this phenomenon has been the struggle between Congress and the judiciary over the scope of congressional control of federal court jurisdiction. The recent controversy over school busing has highlighted this problem. The problem is, however, neither novel nor peculiar to the busing issue. In considering the first judiciary act Congress debated the scope of its authority to regulate the jurisdiction of the federal courts. ${ }^{4}$ In the last twenty years unpopular decisions by federal courts, particularly the Supreme Court, have led to serious discussions of curtailing federal court jurisdiction.

After Brown v. Board of Education ${ }^{5}$ there was a movement to withdraw Supreme Court jurisdiction to hear school desegregation cases." During and after the McCarthy era, and perhaps in response to it, the Supreme Court conferred upon citizens what some felt to be unduly broad protection from legislative investigations. ${ }^{7}$ This prompted

† A.B. 1969, Swarthmore College; J.D. 1972, University of Pennsylvania; member of the Pennsylvania Bar.

1. See, e.g., State Highway Comm'n v. Volpe, 41 U.S.L.W. 2539 (8th Cir. Apr. 2, 1973); Note, Impoundment of Funds, 86 HARv. L. Rev. 1505 (1973); Note, Protecting the Fisc: Executive Impoundment and Congressional Power, 82 YaLE L.J. 1636 (1973).

2. See, e.g., Holtzman v. Schlesinger, 484 F.2d 1907 (2d Cir.), rev'g Holtzman v. Richardson, 361 F. Supp. 553 (E.D.N.Y. 1973); Lofgren, War-Making Under the Constitution: The Original Understanding, 81 YaLE L.J. 672 (1972).

3. See, e.g., Marbury v. Madison, 5 U.S. (1 Cranch) 137 (1803).

4. See Warren, New Light on the History of the Federal Judiciary Act of 1789, 37 HARV. L. REv. 49, 67-70 (1923).

5. 347 U.S. 483 (1954).

6. H.R. 1228, 85th Cong., 1st Sess. (1957), would have deprived federal courts of jurisdiction to hear any suit questioning state laws relating to public schools. See also S. 3467, 85th Cong., 2d Sess. (1958) (depriving the Supreme Court of appellate jurisdiction in cases attacking state public school systems "on grounds other than substantial inequality of physical facilities and other tangible factors").

7. See generally Comment, Legislative Inquiry Into Political Activity: First Amendment Immunity From Committee Interrogation, 65 YALE L.J. 1159 (1956). 
a proposal to curtail Supreme Court jurisdiction to review cases involving contempt of Congress, as well as cases involving state and federal regulation of subversive activities. ${ }^{s}$ After Reynolds $v$. Sims ${ }^{2}$ a bill which passed the House of Representatives would have withdrawn jurisdiction from the Supreme Court and the district courts to hear cases in which plaintiffs sought to force reapportionment of state legislatures. ${ }^{10}$ From 1953 to 1969 over 60 unsuccessful bills were introduced in Congress to curtail some aspect of federal jurisdiction. ${ }^{11}$ Today, because of a number of district court decisions ordering the busing of schoolchildren to overcome segregation, ${ }^{12}$ the issue of congressional dominion over federal court jurisdiction is again of vital national importance. ${ }^{13}$

8. See S. 2646, 85th Cong,, 2d Sess. (1958). It was defeated in the Senate. 104 Conc. REC. 18687 (1958).

9. 377 U.S. 533 (1964).

10. The bill, introduced by Representative Tuck, read in part:

The Supreme Court shall not have the right to review the action of a Federal court or a State court of last resort concerning any action taken upon a petition or complaint seeking to apportion or reapportion any legislature of any State of the Union or any branch thereof . . . .

The district courts shall not have jurisdiction to entertain any petition or complaint seeking to apportion or reapportion the legislature of any State of the Union or any branch thereof ....

H.R. 11926, 88th Cong., $2 \mathrm{~d}$ Sess. (1964). The bill was defeated in the Senate. 110 Conc. REC. 22104 (1964).

11. See P. Bitor, P. Mishkin, D. Shapiro \& H. Wechsler, Hart \& Wechsler's The Federal Courts and The Federal SysteM 360 (2d ed. 1973) [hereinafter cited as Bator]. The focus on relatively recent times is not meant to suggest that the phenomenon is a new one. See C. Leonard, a Search for a Judicial Philosophy: Mr. Justice Roberts and tue Constitutional. Revolution of 1937, at I (1971); 2 C. Warren, The Supreme Court in United States History 117-18 (1922) (Senator Johnson's proposal for Senate review of cases to which a state is a party); Mckay, Court, Congress, and Reapportionment, 63 Mich. L. REv. 255 (1964).

Another recent instance was Senator Dirksen's bill to curtail federal court activity in obscenity cases. S. 4058, 90th Cong., 2d Sess. (1968). The bill was discussed in Note, Removal of Supreme Court Appellate Jurisdiction: A Weapon Against Obscenity?, 1969 DUKE L.J. 291.

12. See, e.g., Swann v. Charlotte-Mecklenburg Bd. of Educ., 311 F. Supp. 265 (W.D. N.C. 1970), aff'd, 402 U.S. 1 (1971). See generally Note, The Nixon Busing Bills and Congressional Power, 81 YaLe L.J. 1542, 1543 n.7 (1972).

13. See, e.g., H.R. 10693, 92d Cong., 1st Sess. (1971). Most proposals in response to busing have been in the form of constitutional amendments. H.J. Res. 1035, 92d Cong., 2d Sess. (1972); S.J. Res. 165, 92d Cong., lst Sess. (1971); H.J. Res. 30, 823, 856, 858, 92d Cong., Ist Sess. (1971). The busing bills backed by the Nixon administration have attracted the most attention. H.R. 13915, 13916, 92d Cong., 2d Sess. (1972). They are discussed in detail in Goldberg, The Administration's Anti-Busing Proposals-Politics Makes Bad Law, 67 Nw. U.L. REv. 319 (1972); Thompson \& Pollitt, Congressional Control of Judicial Remedies: President Nixon's Proposed Moratorium on "Busing" Orders, 50 N.C. L. REv. 809 (1972); Note, Moratorium on School Busing for the Purpose of Achieving Racial Balance: A New Chapter in Congressional Court-Curbing, 48 NoTrx DAME LAWYER 208 (1972) [hereinafter cited as Note, Moratorium on School Busing]; Note, supra note 12.

The version of the bill that passed the House forbids court-ordered busing of students beyond the two schools closest to their home:

Sec. 403. (a) No court, department, or agency of the United States shall, pursuant to section 402, order the implementation of a plan that would require the transportation of any student to a school other than the school closest or next closest 
During the current controversy there have been two approaches to the subject of Congress' control of federal jurisdiction. The position taken most often in contemporary debate begins with the assumption that Congress has authority to abolish the lower federal courts. ${ }^{14}$ Since Congress has the power to abolish, this argument runs, Congress must have plenary control over inferior federal jurisdiction. $^{15}$ Others have begun with the same assumption but feel that a resolution of the subsequent questions is not so easily achieved. Must Congress, they ask, to satisfy Article III, vest jurisdiction in some federal court to hear all cases within the federal judicial power? ${ }^{10}$ What are the limits on congressional control of Supreme Court jurisdiction ? $^{17}$ If Congress can remove an entire class of cases from the district court level, can Congress also limit the remedies available to a court once it is given jurisdiction to hear a case ${ }^{18}$ Virtually all of those who have engaged in this contemporary debate, however, assume that Congress may abolish the lower federal courts. ${ }^{19}$

That such an important assumption should be unquestioned in the current furor over busing is surprising. Clearly it limits the range of argument open to those favoring broad mandatory federal jurisdiction. If the assumption is false, inquiry should be redirected to whether Congress may selectively withdraw jurisdiction to grant

to his place of residence which provides the appropriate grade level and type of education for such student.

H.R. 13915, 92d Cong., 2d Sess. (1972) (as it passed the House and was introduced in the Senate on August 18, 1972). Although the bill is not phrased in jurisdictional terms, it would be a triumph of form over substance to fail to analyze it in such terms. See Note, supra note 12, at 1546.

14. See Glidden Co. v. Zdanok, 370 U.S. 530, 551 (1962) (dictum); BAtor, supra note 11, at 12; Currie, The Federal Courts and the American Law Institule, $36 \mathrm{U}$. CHI. L. REv. 1, 2-3 (1968); Hill, Constitutional Remedies, 69 Colum. L. REv. 1109, 1117 (1969); Note, Moratorium on School Busing, supra note 13, at 209.10.

15. Ratner, Congressional Power Over the Appellate Jurisdiction of the Supreme Court, 109 U. PA. L. Rev. 157, 158 (1960). See Lockerty v. Phillips, 319 U.S. 182, 187 (1943); Kline v. Burke Constr. Co., 260 U.S. 226, 234 (1922); United States v. Union Pacific R.R., 98 U.S. 569, 603 (1878); Sheldon v. Sill, 49 U.S. (8 How.) 441 (1850).

16. The earliest person to question the majority position appears to have been Henry Wheaton in 1821. Bator, supra note 11 , at 314-15 n.2. It is repeated in Eisen. stager v. Forrestal, 174 F.2d 961, 965-66 (D.C. Cir. 1949). Although wheaton accepted the basic proposition he contended that Congress is compelled to grant the Stupreme Court appellate jurisdiction to review all matters within the federal judicial power.

17. See Freund, Storm Over the American Supreme Court, 21 MODERN L. REV. 345 (1958); Levy, Congressional Power Over the Appellate Jurisdiction of the Supreme Court: A Reappraisal, 22 N.Y.U. InrRA. L. Rev. 178 (1967); Merry, Scope of the Supreme Court's Appellate Jurisdiction: Historic Basis, 47 Minv. L. REv. 53 (1962); Ratncr, supra note 15; Roberts, Now is the Time: Fortifying the Supreme Court's Independence, 35 A.B.A.J. I (1949).

18. Thompson \& Pollitt, supra note 13, at 823-27; Note, supra note 12 , at 1546 n.19, 1549 .

19. See note 14 supra. 
a particular remedy from district courts and to whether it may withdraw a particular case or class of cases from those tribunals. ${ }^{20}$

This article will attempt to demonstrate that the premise that Congress may abolish the lower federal courts is false. Such courts may in the beginning have been a luxury for the young nation. Today they are almost as necessary as the Supreme Court in performing the functions given the federal judiciary in the Constitution. "The life of a nation"'21 has come to depend in no small degree on these bodies and their too hastily assumed mortality should be a matter of general concern. If it is true, as I argue, that inferior federal courts may not be abolished, then resolution of the corollary questions of whether Congress can selectively curtail jurisdiction or resort to certain remedies is more difficult.

\section{May Congress Abolish the Lower Federal Courts?}

\section{A. The Traditional View}

Article III of the Constitution is the starting point for analysis of this question:

Section 1. The judicial Power of the United States, shall be vested in one supreme Court, and in such inferior Courts as the Congress may from time to time ordain and establish. . . .

Section 2. The judicial Power shall extend to all Cases, in Law and Equity, arising under this Constitution, the Laws of the United States, and Treaties made, or which shall be made, under their Authority;-to all Cases affecting Ambassadors, other public Ministers and Consuls; - to all Cases of admiralty and maritime Jurisdiction;-to Controversies to which the United States shall be a Party;-to Controversies between two or more States;between a State and Citizens of another State;-between Citizens of different States;-between Citizens of the same State claiming Lands under Grants of different States, and between a State, or the Citizens thereof, and foreign States, Citizens or Subjects.

The foregoing text is open to several interpretations with regard to Congress' power over lower tribunals. It states that the judicial

20. The primary focus of this article is on the power of Congress to abolish, curtail the jurisdiction of, or remove remedies from, the lower federal courts. There is a very closely related question as to the authority of Congress to restrict the jurisdiction of both the lower federal courts and the Supreme Court under the jurisdictional power and the exceptions clause of Article III. U.S. ConsT. art. III, § 2. For a discussion of the aspects of this question that I will not address see Blumstein, The Supreme Court's Jurisdiction-Reform Proposals, Discretionary Review, and Writ Dismissals, 26 VAND. L. REV. 895 (1973).

21. A. Bickel, The Leist Dangerous Brancir 14 (1962) (writing about judicial review). 
power shall be vested in one Supreme Court "and in such inferior Courts as the Congress may from time to time ordain and establish." The quoted phrase can be interpreted to mean that Congress may establish lower federal courts on a discretionary basis. An equally rational reading of Article III leads to a contrary conclusion. Section 2 gives the federal judiciary power to hear in the first instance many cases which are not within the Supreme Court's original jurisdiction. ${ }^{22}$ Thus, there is a gap between the full reach of federal judicial power and that which is conferred originally by the Constitution on the Supreme Court. This gap, when read in conjunction with the "shall" of $\$ 1$, suggests that there must be inferior courts to exercise the residuum of federal jurisdiction withheld from the Supreme Court. This proposition is supported as well by the fact that $\$ 2$ originally read "the jurisdiction of the Supreme Court" and was changed to read "The judicial Power."23 It thus seems clear that lower courts were intended to be covered.

An interpretation of Article III much like the second one set forth above was advocated long ago. In Martin v. Hunter's Lessee ${ }^{24}$ Justice Story concluded from the phrase "shall be vested" that the whole federal jurisdictional power must be vested in some federal court. Since Article III gave federal courts jurisdiction wherever the Supreme Court lacked original jurisdiction, it followed

that congress [was] bound to create some inferior courts, in which to vest all that jurisdiction which, under the constitution, is exclusively vested in the United States, and of which the supreme court cannot take original cognizance. ${ }^{25}$

Justice Story later repeated this position ${ }^{26}$ and, in a modified form, it has found some support. 27

Justice Story's dicta might have carried the day but for the argu-

22. "In all cases affecting Ambassadors, other public Ministers and Consuls, and those in which a State shall be Party, the Supreme Court shall have original jurisdiction." U.S. CoNsT. art. III, $\$ 2$, cl. 2. A constitutional challenge to a federal statute, for instance, would be within the ambit of the federal judicial power but not within the Supreme Court's original jurisdiction.

23. Ratner, supra note 15 , at 164. James Madison and Gouvernor Morris recommended this change and it was accepted by the entire Convention without any debate. M. FARrand, Records of THE Federal Convention of 1787, at 425, 431 (1911) [hereinafter cited as FARRAND].

24. 14 U.S. (1 Wheat.) 304, 328-31 (1816) (dictum).

25. Id. at 331 (emphasis in original). This theory originated not with Justice Story but with Gouvernor Morris. 3 FARRAND, supra note 23, at 391 (App. A) (addressing Congress).

26. 3 J. Story, Commentaries on THE Constitution $\$ \$ 1590-94$, at $409-12$ (1891). $\Lambda$ discussion of the early debate on this topic may be found in Warren, supra note 4 , at $68-70$.

27. See 1 M. Crosskey, Politics and the Constitution in the History of the UNITED States 613-16 (1953). 
ment made popular by two distinguished scholars. Professors Hart and Wechsler argued forcefully for the first interpretation. They contended that the phrasing of Article III reflected a decision by the Constitutional Convention to leave establishment of inferior federal courts to the discretion of Congress. ${ }^{28}$ This decision seems to have been a compromise between those who favored mandatory inferior federal courts and those who believed that state courts could and should perform the trial functions. ${ }^{29}$ Thus while Congress was given authority to create new courts, it was not compelled to do so. ${ }^{30}$

The Hart and Wechsler argument has for a long time preempted serious debate on the significance of the ambiguities in Article III. Recently, however, Professor Goebel has argued that the words "ordain and establish" in Article III, ${ }^{31}$ when viewed in light of their meaning in 1787, demonstrate that the Convention intended that lower federal courts should be created. As originally submitted to the Committee of Style, the draft had read:

The Judicial Power of the United States both in law and equity shall be vested in one Supreme Court, and in such Inferior Courts as shall, when necessary, from time to time, be constituted by the Legislature of the United States. ${ }^{32}$

Goebel guesses that the change from the original submission to the current language reflected a victory for the "four stalwart nationalists" on the Committee. ${ }^{33}$ Goebel summarizes:

That the Committee [of Style] intended to convey the sense of an imperative is apparent from the choice of the most forceful words in the contemporary constitutional vocabulary-"ordain and establish"-to direct what Congress was to do. ${ }^{34}$

28. B.tToR, supra note 11, at 11-12. The proposal for inferior tribunals was contained in Randolph's Virginia Plan. I FARRAND, supra note 23, at 21-22. It was initially passed by the Committee of the Whole on June 4, 1787. Id. at 95. The next day, however, John Rutledge moved for and obtained reconsideration of the provision. After reconsideration the Committce voted to give the national legislature discretion to establish lower courts, 2 Farrand 125, a position later adopted by the Convention. But see $1 \mathrm{~J}$. Goeber, History of the Supreme Court of the United States: Antecenents AND BEGINNINGS To 1801 , at 243 n.228 \& 247 (1971).

29. See $3 \mathrm{~J}$. STorY, supra note $26, \$ 1580$, at 404 .

30. I Firrand, supra note 23, at 125. See also Sherman, A Citizen of New Haven, II (originally published on Dec. 25, 1788, in the New Haven Gazette), reprinted in Ess.tY' oN THE Coxstitution of THE United STATES 237, 241 (P. Ford ed. 1892) [hereinafter cited as Essays]; Webster, An Examination Into the Leading Principles of the Federal Constitution Proposed By the Late Convention Held at Philadelphia. With Answers to the Principal Objections that Have Been Raised Against the System (originally published on Oct. 10, 1787), reprinted in PAMPHLETS ON THE CONSTITUTION OF THE UnITED STATEs 24, 53 (P. Ford ed. 1888) [hereinafter cited as PAMPHLETs].

31. The relevant text of Article III is set forth in the text at p. 501 supra.

32. $1 \mathrm{~J}$. GoEbeL, supra note 28 , at 246.

33. Id. at 247 .

34. Id. 
Professor Goebel's interpretation of the words in their 1787 context suggests another approach to the question whether lower federal courts must exist, one that emphasizes the context in which Article III was written. If this approach fails the Hart-Wechsler view must prevail, for, based solely on the debates at the Constitutional Convention, their position seems to have the edge over those of Justice Story and Professor Goebel. Viewing the compromise in context, however, it is doubtful that the lower federal courts are dispensable.

\section{B. A New Thesis}

The traditional position on abolition of the lower federal courts relies exclusively on an interpretation of one discrete compromise at the Convention. It thus ignores other constitutional realities that suggest that the lower federal courts cannot be abolished. If that argument is to have contemporary validity, it must come to terms with circumstances affecting the framers' decision and their view of the national judiciary's functions. If, because of changing circumstances, the framers' aspirations for the national judiciary cannot be fulfilled today without lower federal courts, ${ }^{35}$ then there is a conflict between the Hart and Wechsler view of the decision to leave creation of lower courts to Congress' whim and the constitutional definition of the judiciary's role. Ignoring the compromise emphasized by Hart and Wechsler would involve abandonment of a formulation not central to the constitutional scheme. The existence of lower federal courts since the first Congress suggests that the terms of the compromise are not essential to the constitutional plan. On the other hand a decision to limit the legitimate role of the national judiciary would weaken one branch of government, perhaps fatally. The critical functions performed by the lower courts $^{36}$ suggest their continued vitality may be, in Learned Hand's phrase, "essential to prevent the defeat of the venture at hand . . .."37

35. Cf. United States v. Classic, 313 U.S. 299, 316 (1941); Home Bldg. \& Loan Ass'n v. Blaisdell, 290 U.S. 398, 443 (1934). These cases support the propriety, perhaps even the necessity, of reinterpreting early constitutional formulations in light of changed circumstances. See also note 51 infra. Even so fervent an advocate of judicial restraint as Professor Phillip Kurland has recognized that changed conditions may require broadening the federal judiciary's constitutional role. In the context of the cxecutive branch's expansion in modern times and the threat posed by such enlargement to our constitutional system, he states, "[T] he Court would remain true to its function of preserving the original meaning of the Constitution if it were to act more aggressively to help prevent the executive from overreaching his constitutionally limited function." P. Kurland, Politics, the Constitution, ANd the Warren Court 17 (1970).

36. See pp. 510-13 infra.

37. L. HAND, THE BILL OF RIGHTS 14 (1958) (writing of judicial review). Judge Friendly rejects the view that the constitutional grant of federal jurisdiction could be allocated without creating lower federal courts. H. Friendey, Federal Jurisdiction: A General View 7-13 (1973). 
The national judiciary was intended to perform a number of roles. Perhaps the most central is its power to check the other two branches of government. ${ }^{38}$ The Supreme Court inhibits attempts by the other branches to overstep constitutionally mandated boundaries of authority. Two other functions of the national judiciary are closely related. First, it is the judiciary's task to achieve uniformity of decision on questions of national concern. ${ }^{39}$ Second, a national judiciary helps ensure that federal interests take precedence over those of any particular state in matters of federal competence. The framers' interest in institutionalizing these two functions is best illustrated by the colonies' judicial endeavors during the Revolutionary War.

During the war the colonies commissioned vessels to harass British shipping. General Washington sought guidance from the Continental Congress regarding the disposition of booty acquired in successful harassments, ${ }^{40}$ suggesting that courts be established to handle disbursement of the prizes. ${ }^{41}$ The Continental Congress resolved ${ }^{42}$ that state courts should handle prizes and provided an appeal to the Congress from state court determinations. At first, review was by congressional committee, but in 1781 Congress established the Court of Appeals in Cases of Capture. ${ }^{43}$ This court and its predecessor, the congressional committee, were necessary because some overexuberant privateers had seized ships belonging to neutrals ${ }^{44}$ and state courts were not always sympathetic to neutrals' claims. ${ }^{45}$ Since the Continental Congress was seeking the assistance of neutrals, it created a national tribunal to prevent state authorities from hindering that effort. This example of protecting the united interest over that of a particular state $e^{40}$ and of a mechanism to assure some degree of

38. See R. Brrger, Congress v. The Suprene Court 8-16 (1969); G. Dietze, The Federalist $172(1960)$. This has been disputed by Professor Crosskey. For a statement of Crosskey's position and an effective refutation sec R. BERGER, supra at 19-20.

39. See 1 Farrind, supra note 23, at 124; 3 J. Eldiot, Debates in the Severat. State Conventions on the Adoprion of tHe Federil Constitution 532 (1836) [hereinafter cited as Ellior].

40. See BATOR, supra note 11, at 5 n.18; J. GoEBEL, supra note 28, at 147.

41. S. Bloom, History of the Formation of THE UNion UNDER the Constitution $347-48$ (1940).

42. For an explanation of the legal effect of a "resolve" by the Continental Congress see $\mathrm{J}$. GoEBEL, supra note 28 , at 146.

43. There is some doubt as to the court's legality since the Articles of Confederation had not yet been accepted by all the states. Id. at 164 .

44. Id. Concern over state indiscretions in prize cases was still present at the Constitutional Convention. The Virginia Plan, the New Jersey Plan, and Alexander Hamilton's Plan expressly provided for federal jurisdiction in capture cases. I FarRand, supra note 23, at 22, 244, 292.

45. See 2 Elloor, supra note 39, at 494 (Wilson at Pennsylvania deliberations).

46. See 3 Exrior, supra note 39 , at 532 (Madison at Virginia deliberations); I FARRAND, supra note 23, at 316 (Madison); Lee, Letters of a Federal Farmer, Letter III, reprinted in PAMPHLET, supra note 30 , at 294, 309. 
decisional uniformity was clearly a factor in shaping the notion of a national judiciary as developed at the Convention.

National courts were also to provide a forum in which foreigners, out-of-state litigants, ${ }^{47}$ and the new government itself might get a fair hearing. ${ }^{48}$ The lawyers at the Constitutional Convention were well aware of the local biases of state courts. ${ }^{49}$ Finally, the new government would need a judiciary of its own to ensure proper implementation of its laws. 50

The list of functions could be extended, an exercise not necessary for present purposes. ${ }^{51}$ There was, however, at least one other vital function: The national judiciary was intended, perhaps above all else, to be able to hear and do justice in all cases within its jurisdiction. In the 1780 's, not unlike today, "[c]ourts were thought of in part ... as instruments for the protection of individuals." Two of the most influential delegates to the Constitutional Convention stressed the federal judiciary's role as a protector of citizens. At the Convention itself Gouverneur Morris stated that everyone had witnessed "excesses against personal liberty, private property and personal safety." $\overline{3}$ In one of the Federalist Papers Hamilton emphasized that the courts must protect individuals from legislative tyranny:

Limitations on legislative authority can be preserved in practice no other way than through the medium of the courts of justice, whose duty it must be to declare all acts contrary to the manifest tenor of the Constitution void. Without this, all reservations of particular rights or privileges would amount to nothing. ${ }^{54}$

47. See Bator, supra note 11, at 17; 2 Ellior $492-93$ (Wilson at Pennsylvania deliberations).

48. See, e.g., 2 FARRAND, supra note 23, at 46 (Randolph); Hanson, Remarks on the Proposed Plan of a Federal Government, Addressed to the Citizens of the United States (originally published Jan. 1, 1788, under pen name Aristedes), reprinted in Pamphlers, supra note 30, at 217, 238; Ellsworth, The Landholder $V$ (originally published Dec. 3, 1787, in the Connecticut Courant), reprinted in Essays, supra note 30 , at 159.

49. See J. Goeber, supra note 28 , at 206.

50. See, e.g., 2 ELLIOT, supra note 39, at 469 (Wilson at Pennsylvania deliberations). 2 Farrand, supra note 23, at 46 (Randolph); The Federalist No. 80, at 515-16 (MIod. Lib. ed. 1941) (A. Hamilton).

51. See BATOR, supra note 11 , at 12-18.

52. Id. at 6 n.19.

53. I FarRand, supra note 23 , at 512 .

54. The Federalist No. 78, at 466 (New Am. Lib. ed. 1961). See G. DiEtze, supra note 38 , at 172. James Madison also argued that the new government must make provision for the protection of individual rights. BATOR, supra note 11, at 6 n.19 (quoting Madison). Madison noted that the need for steady dispensation of justice was one fact which "more perhaps than anything else, produced this convention." I FarRaND 134. 
The state ratification debates also indicate that it was commonly assumed that the federal judiciary would vindicate private rights within the federal jurisdiction. ${ }^{55}$ The diversity jurisdiction in the Constitution was designed to give litigants a chance to obtain an impartial tribunal.jo There was no suggestion that the national judiciary or Congress had the power to choose which of the rights set forth in the text of the Constitution would be vindicated. At the Virginia deliberations on the proposed constitution, Supreme Court jurisdiction was said to be intended "to prevent injustice by correcting the erroneous decisions of local subordinate tribunals . . .."57 This can only mean to do justice in each individual case which falls under the federal jurisdiction, even if by appellate review. ${ }^{58}$

This emphasis on the national judiciary's role as vindicator of private and individual rights strongly suggests that the framers intended that national tribunals would hear each case within the federal judicial power. Hamilton is again instructive:

The evident aim of the plan of the convention is, that all the causes of the specified classes shall, for weighty public reasons receive their original or final determination in the courts of the Union. ${ }^{59}$

There can be little doubt that the early Supreme Court did in fact supply a final determination of those cases appealed to it, no matter how trivial the matter might appear from a national perspective. ${ }^{60}$

The judiciary would also be unable to check legislative abuses if its jurisdiction were limitable at the discretion of Congress. ${ }^{81}$ To assume that the framers desired both to control the legislature by means of the federal courts and to give the legislature a method for nullifying such control by a simple majority vote approving a jurisdictional statute is "to charge them with chasing their tails around a stump."

55. See R. BERGER, supra note 38 , at $16-20$.

56. See 2 Elliot, supra note 39 , at 491 (Wilson at Pennsylvania deliberations).

57. 3 Ellor 518 (Pendleton at Virginia deliberations).

58. See id. at 535 (Madison suggesting federal appellate jurisdiction will guard against local prejudice).

59. The Federalist No. 82, at 494 (New Am. Lib. ed. 1961).

60. See Frank, Historical Bases of the Federal Judicial System, 13 LAw \& ConTEMP. Prob. 3, 17 (1948). This view of the Supreme Court was dominant for many years. It led some to resist in 1891 the establishment of intermediate federal appellate tribunals. F. Frankfurter \& J. Landis, The Business of the Surreme Court 258 (1928).

61. Raoul Berger believes restraining state and federal legislative bodies was a reason for creating the federal judiciary. R. BERGER, supra note 38, at 8-16, 336. His view has substantial support. See note 38 supra.

62. Berger makes this argument in support of his thesis that judicial review is implicit in the constitutional scheme. R. BERGER 336-37. 
A compelling indication that the framers intended the federal judiciary to be capable of affording a forum for all cases within its jurisdiction comes from an omission from Article III. Neither the final arrangement nor any of the five judiciary plans submitted to the Convention gave federal courts authority to decline to hear a case. ${ }^{63}$ Discretionary review by the Supreme Court did not originate until $1925 .{ }^{64}$ The framers' failure to confer, or even consider conferring, discretionary review powers upon courts suggests that federal tribunals, including the Supreme Court, were thought capable of providing a forum in all cases within their jurisdiction. ${ }^{65}$

One is tempted to ask how the framers could both intend the federal judiciary to be capable of hearing all cases within its jurisdiction and at the same time not explicitly incorporate inferior federal courts into the constitutional scheme. The answer is that the founding fathers felt that the right to appellate review by the Supreme Court would be sufficient to ensure that all litigants with cases within the federal constitutional jurisdiction would have their cases heard by a national tribunal. ${ }^{60}$ This faith in the availability of Supreme Court review was in evidence at the Constitutional Convention. ${ }^{67}$ Rutledge employed it as a rationale for not including any lower federal courts in the constitutional scheme. ${ }^{68}$ Luther Martin explained to his fellow Marylanders that he did not think that lower federal courts were necessary because, "by giving an appeal to the Supreme Court of the United States, the general government would have a sufficient check over [state] decisions and security for the enforcing of their laws ...." Undoubtedly the same confidence was

63. See 1 FARRAND, supra note 23 , at $20-22$ (Virginia plan); 3 id. at $106-23,595 \cdot 610$ (Pinckney plan); 1 id. at 242-45 (Paterson plan); 1 id. at 291-93, 617-30 (Hamilton plan); 2 id. at 432 (Blair plan). See also 2 id. at 136.

64. Although statutory certiorari was first employed at the Supreme Court level as an appellate procedure in 1891, Act of March 3, 1891, 26 Stat. 826, 828; D. CurRIr, FEDERAL Courts 217 (1968), it was not used to curtail the right to Supreme Court review until passage of the Judiciary Act of 1925, 43 Stat. 936 (Judges' Bill); R. RoberTsoN \& F. Kirkham, JuRisdiction of The SUpreme Court of THE UNited STites $\$ 310$, at 589 (R. Wolfson \& P. Kurland eds. 1951). In the 1891 act certiorari expanded rather than contracted Supreme Court review. See F. FrANkfurter \& J. LANDIs, supra note 60, at 261; R. Robertsox \& F. Kirkham, supra $\$ 310$, at 589-90. See also Act of Sept. 6,1916 , ch. $448, \$ 237,39$ Stat. 726 (giving Supreme Court discretion to decline to hear criminal appeals in which federal contentions had been rejected by state courts).

65. One indication of the common understanding that appeal to a federal tribunal on a federal matter would be as of right is Alexander Hamilton's argument that the creation of lower federal courts "would obviate the necessity of having recourse to the Supreme Court in every case of federal cognizance." THE FEDERALIsT No. 81, at 485 (New Am. Lib. ed. 1961) (emphasis added).

66. The exceptions clause in Article III does not necessarily reflect a contrary view.

See J. GoEBer, supra note 28 , at 240.

67. See Warren, supra note 4 , at 64-67.

68. See 1 FARRAND, supra note 23, at 124.

69. 3 FARrand 206. 
a major factor in the acquiescence of some in the deletion of mandatory inferior tribunals at the Convention.

Others expressed a similar sentiment by noting that they expected few federal cases. If there were to be only a few cases, it is clear that the Supreme Court, by appellate review, would have been capable of exercising the "judicial power of the United States" effectively. Roger Sherman, a delegate to the Convention from Connecticut, later wrote that "it is not probable that more than one citizen to a thousand will even have a cause that can come before a federal court."70 Alexander Hanson, a Maryland federalist, also felt that there would be few federal actions. ${ }^{71}$ Soon after the Convention, James Madison wrote to George Washington, "The great mass of suits in every State lie between Citizen \& Citizen, and relate to matters not of federal cognizance." 72 With but few exceptions ${ }^{73}$ the framers felt that the federal judiciary, due to the constitutional limits on the subject matter of its jurisdiction, would peacefully coexist with state courts, handling only those few cases of federal concern. ${ }^{74}$

Thus commentary at the time of the passage of the Constitution suggests that underlying the exercise of the other functions of the federal judiciary was the notion that the federal courts, whatever their form, could be expected to hear any litigant whose case was within the federal constitutional jurisdiction, either at trial or on appeal. This view is buttressed by the lack of any provision in the Constitution giving the federal courts discretionary jurisdiction. The federal forum may have been limited to appellate review, but it was to be available in all cases.

The framers' apparent willingness to limit the federal role to an appellate role in the form of Supreme Court review was perfectly understandable at the time. Without question, the Supreme Court

70. Sherman, A Citizen of New Haven, II (essay originally published on Dec. 25, 1788, in the New Haven Gazette), reprinted in Essays, supra note 30, at 241.

71. As the rod of Aaron once swallowed up the rods of the Egyptian magi, so also is it feared, that these federal courts, will, at length, swallow up the state tribunals. A miracle, in one case, is as necessary, as in the other.

But let not the officers of state courts be overmuch alarmed! The causes, which,

by possibility, may be instituted in the federal courts bear no comparison to the rest.

Hanson, supra note 48, reprinted in PAMphlets, supra note 30, at 239 (footnote omitted).

72. 3 FarRand, supra note 23 , at 130 .

73. See, e.g., Mason, Objections to the Proposed Federal Constitution, reprinted in P.MMPhLETS, supra note 30, at 327, 329-30. See also W. Brown, ThE LIfE of OLIVER ELLSWORTH 192 (1905).

74. See text accompanying notes 70-72 supra; EllsworTH, supra note 48, reprinted in Fistlys, supra note 30, at 159; Iredell, Answers to Mr. Mason's Objections to the New Constitution, Recommended by the Late Convention (1788), reprinted in Pamphlets 333, 313; Webster, supra note 30 , reprinted in Pamphlets 24, 53. 
was then capable of providing a forum for all federal cases. Between 1789 and 1801 the Supreme Court disposed of fewer than 90 cases. $^{75}$ During the first four terms of the Court, not a single case was argued. ${ }^{70}$ Since the Court's jurisdiction was not discretionary, ${ }^{77}$ any litigant whose case fell within the federal judicial power and who was determined to have a federal forum hear his case could have had such a forum even in the absence of lower federal courts.

Since the early days of the republic, however, the number of federal cases has increased dramatically. During the 1972 term alone the Supreme Court wrote full opinions in 164 cases, ${ }^{78}$ while disposing of 3,748 cases. $^{79}$ This increase in case load has had significant consequences for both the Supreme Court and lower federal courts. The Supreme Court is clearly no longer capable of providing a federal forum to hear the merits of every case involving a federal question. ${ }^{80}$ If Congress were to abolish the lower federal courts, this aspect of the national judiciary's role would fall upon the Supreme Court in the form of review of state court decisions. The inevitable result would be that few litigants with federal claims could be heard in a federal court even on appeal. ${ }^{81}$ The burden of Article III, as understood by the framers, would fall upon one court-the Supreme Court.

As the federal caseload has grown the role of lower federal courts

75. See J. GoEbeL, supra note 28 , at $802-13$.

76. See 1 L. Friedman \& F. Israel, The Justices of the Supreme Court of the United States 42 (1969). The leisurely pace of Supreme Court practice as late as 1848 is set forth in Lowry, The Supreme Court in 1S4S \& 1938: A Review of Two Terms, 23 So. Cal. L. Rev. 459 (1950). In 1848, the Court decided only 36 cases. Id. at 460 .

77. In addition to the absence of certiorari as a device for declining to hear a case, a litigant in 1789 did not have to face the current technique of dismissal of an appeal for want of a substantial federal question. H. FriendLy, supra note 37, at 92-96.

78. See The Supreme Court, 1972 Term, 87 HARv. L. Rev. 303 (1973).

79. Id. at 306 .

80. Judge Friendly has noted that Supreme Court review is even inadequate to protect federal civil rights. H. FriendLy, supra note 37, at 102-03. The expansion of federal habeas corpus in Brown v. Allen, 344 U.S. 443 (1953), "is usually thought to rest primarily on the assumption that constitutional rights cannot be adequately pro. tected by direct Supreme Court review of state court judgments resulting in detention." Bator, supra note 11, at 1475. See Mishkin, Foreword: The High Court, The Great Writ, and the Due Process of Time and Law, 79 Harv. L. Rev. 56, 86-87 (1965); Reitz, Federal Habeas Corpus: Postconviction Remedy for State Prisoners, 108 U. PA. L. REv. 461, 464, 501 (1960).

81. The burden on the Supreme Court would be intolerable, constitutionally and physically. It is worth noting that the recent debate on the proposed National Court of Appeals has concentrated on the question of whether the Supreme Court can perform the two functions of selecting issues and deciding cases in an appropriately contemplative manner. Compare Freund, Why We Need the National Court of Appeals, 59 A.B.A.J. 247 (1973), with Brennan, The National Court of Appeals: Another Dissent, 40 U. CHI. L. Rev. 473 (1973); Gressman, The National Court of Appeals: A Dissent, 59 A.B.A.J. 253 (1973); Poe, Schmidt \& Whalen, A National Court of Appeals: A Dissenting View, 67 Nw. U.L. REv. 842 (1973); and Address by Earl Warren to the Ass'n of the Bar of the City of N.Y., May 1, 1973. 
has undergone change. Today the lower federal courts are more than mere federal trial forums for cases falling within the Article III jurisdictional grant. First, in those instances where the Supreme Court makes a pronouncement of nation-wide impact regarding federal rights or interests, the lower courts are needed to enforce and apply it. Moreover, as Supreme Court review becomes more selective, the lower courts have become the primary vindicators of federal rights. ${ }^{82}$

Cases which dramatically affect the legal system are by now commonplace. Miranda $v$. Arizona, ${ }^{83}$ United States $v$. Wade, ${ }^{84}$ and Gideon $v$. Wainwright ${ }^{85}$ affected and continue to affect the outcome in an enormous number of cases. In the noncriminal area, the reapportionment and desegregation decisions have generated hundreds of lower court cases. ${ }^{86}$ If the burden of enforcing such important decisions and resolving all the subsidiary questions were left to the Supreme Court, it is doubtful that the task could be performed. Judge Carl McGowan has noted the increased latitude available to the Supreme Court in desegregation cases simply because the lower federal courts are there for enforcement and implementation functions: ${ }^{87}$

The promulgation of those principles [announced in Brown $v$. Board of Education] would have provided an infinitely more daunting prospect in the absence of the machinery provided by the inferior federal courts. Their performance in the discharge of this difficult task has been less than even, but is it conceivable that the job could have been entrusted entirely to the state courts, bearing in mind the differences in loyalties and the vulnerability to local pressures inherent in an elective system of judges? The federal judges themselves have, even with the security provided them by the Constitution, found the going hard.

82. As one might guess, there is no discussion of this eventuality by the framers, for they at least publicly claimed that the number of cases within the federal judicial power would be few. Hamilton, however, was of the view that the lower federal courts were to be the first line of defense in protecting the liberties and rights secured to individuals by the Constitution:

We have seen, that the original jurisdiction of the Supreme Court would be con-

fined to two classes of causes, and those of a nature rarely to occur. In all other

cases of federal cognizance, the original jurisdiction would appertain to the inferior [federal] tribunals; and the Supreme Court would have nothing more than an appellate jurisdiction .....

THE FFDERAlist No. 81, at 488 (New Am. Lib. ed. 1961) (A. Hamilton).

83. 384 U.S. 436 (1966).

84. 388 U.S. 218 (1967).

85. 372 U.S. 335 (1963).

86. See H. FRIENDLY, supra note 37 , at 18-19.

87. C. MrcGowan, The Organization of Judicial Power in the United States 15 (1967). 
It is not fanciful to think that it would have been too much for unsheltered state judges .... . Certainly it would have been hard to have asked them to risk such an exposure with so few shields. ${ }^{8 s}$

Similarly, the success of innovative Supreme Court action in other areas, such as reapportionment and criminal procedure, has rested in substantial part upon the support of the lower federal courts. ${ }^{\text {s9 }}$

The lower federal courts are even more important where the Supreme Court chooses to remain silent. To a significant extent the contemporary guarantors of federal rights are not the nine Supreme Court Justices but the judges of the district courts and courts of appeals. ${ }^{90}$ The lower judges are not authorized to decline to hear a federal matter within their jurisdiction."1 Hundreds of important issues are determined with practical finality by lower federal judges. ${ }^{92}$ During the 1949 Term it was said that the Court failed to consider on the merits a number of cases "which raised the most vital constitutional problems that could be presented to any court in a democratic country."93 No doubt the same could be said of more recent terms. ${ }^{94}$

Caseload increases also have a related effect on the Supreme Court's theoretical role. The heavy use of the Justices' discretion to determine what few cases the Court will hear on the merits makes it impossible to maintain the fiction that every litigant has the right

88. Id. at 16 .

89. Id. at 17-18.

90. For a few years Professor Harper and others collected and discussed the important cases which the Supreme Court had declined to hear. See Harper \& Leibowitz, What the Supreme Court Did Not Do During the 1952 Term, 102 U. PA. L. REv. 427 (1954); Harper \& Pratt, What the Supreme Court Did Not Do During the 1951 Term, 101 U. PA. L. Rev. 439 (1953); Harper \& Etherington, What the Supreme Court Did Not Do During the 1950 Term, 100 U. PA. L. REv. 354 (1951); Harper \& Rosenthal, What the Supreme Court Did Not Do in the 1949 Term, 99 U. PA. L. REv. 293 (1950).

91. It is true that under the abstention doctrine a federal court may dicline to consider a matter when it appears that state courts will afford full justice. H. FRIENDLr, supra note 37, at 95. Abstention is not, however, a denial or surrender of jurisdiction but an exercise of federal restraint pending the outcome of the state proceeding. If state law determines the result, the issue is mooted and federal judicial resources conserved by the operation of the doctrine. Abstention is not, in theory, a method for federal courts to decline to hear federal matters; it is, rather, a delaying technique pending resolution of state issues. See Note, Federal-Question Abstention: Justice Frankfurter's Doctrine in an Activist Era, 80 HARv. L. REv. 604 (1967).

92. In 1967, thirteen years after Brown, Judge Wisdom noted that, even in so important an area as de facto segregation, the lower courts were the main policy: making tribunals. Wisdom, The Frictionmaking, Exacerbating Political Role of Federal Courts, 21 Sw, L.J. 411, 426 (1967).

93. Harper \& Rosenthal, supra note 90, at 323. The Vinson Court's response to McCarthyism was to deny certiorari "in the cases presenting the most fundamental, substantive challenges to the investigatory powier." R. MCCLoskey, THE MODERN SuPREME COURT 73 (1972).

94. See, e.g., DaCosta v. Laird, 448 F.2d 1368 (2d Cir. 1971), cert. denied, 405 U.S. 979 (1972) (constitutionality of United States involvement in the Vietnam War). 
to resort to the Court for vindication of his federal claim. ${ }^{95}$ The Court can no longer resolve all federal cases. The Court's role today, by necessity, is to service issues rather than to do justice for all litigants. ${ }^{90}$ Justice Frankfurter, before he served on the Court, wrote that the essential functions of the Supreme Court are "[to] resolve conflicts among coordinate appellate tribunals and to determine matters of national concern." 97 Indeed, the Court's own rule governing grants of certiorari reveals a bias torvard issues rather than litigants and their particular rights. ${ }^{98}$

This shift in the Supreme Court's function has meant that it must decline to hear most cases. The modern Court has no qualms about refusing to decide a case or controversy even when it has jurisdiction to do so. It may prefer to hear a case in which a particular issue is presented in a "clean-cut" manner, ${ }^{99}$ on a more complete record, ${ }^{100}$ or simply under "more appropriate circumstances." 101 Whatever one thinks of such techniques, they illustrate the modern Court's understanding of its function.

It is thus no longer reasonable to assert that Congress may simply abolish the lower federal courts. When Supreme Court review of all cases within Article III jurisdiction was possible, lower federal courts were perhaps unnecessary. As federal caseloads grew, however, lower federal courts became necessary components of the national judiciary if the constitutional duty of case by case consideration of all federal cases was to be fulfilled. It can now be asserted that their existence in some form is constitutionally required. ${ }^{102}$

\section{See note 60 supra.}

96. Sec F. Frankfurter \& J. Landis, supra note 60, at 257; R. Robertson \& F. KiRKIIAM, supra note 64 , at 588-89.

97. F. Frinkfurter \& J. Landis, supra note 60, at 257. Professor Charles Miller defined the modern Supreme Court's role as follows:

The Supreme Court performs two overlapping roles in American political life.

The first is to maintain and enunciate a political-legal order through formal ad-

judication. The second is to preserve the social-political bonds of the nation.

C. Miller, The Supreme Court and the Uses of History 189 (1969). See also C. Swisher, The Surreme Court in MODERN Role 171-89 (rev. ed. 1965). A dramatic illustration of the fact that the Court is no longer seen as an organ to protect all rights is the proposal of the Federal Judicial Center Study Group on the Case Load of the Supreme Court. See note 81 supra.

98. Supreme Court Rule 19 states, in part: "A review on writ of certiorari is not a matter of right, but of sound judicial discretion, and will be granted only where there are special and important reasons therefor." Sup. Ct. Rule $19(1)$.

99. Rescue Army v. Municipal Ct., 331 U.S. 549, 584 (1947).

100. See Simmons v. West Haven Housing Authority, 399 U.S. 510,511 (1970); International Bhd. of Teamsters v. Denver Milk Producers, Inc., 334 U.S. 809 (1948).

101. DeBacker v. Brainard, 396 U.S. 28, 29-30 (1969); Naim v. Naim, 350 U.S. 891 (1955), 350 U.S. 985 (1956). Compare Poe v. Ullman, 367 U.S. 497 (1961), with Epperson v. Arkansas, 393 U.S. 97 (1968).

102. A similar line of reasoning was employed by Professor Hart in his well-known argument that, although the "exception clause" of Article III gives Congress much power over the Supreme Court's appellate jurisdiction, Congress cannot wield that 


\section{Congressional Control of Lower Federal Court Jurisdiction}

The conclusion that lower federal courts must exist, though of singular importance, really marks the beginning of a more serious inquiry into the scope of mandatory federal court jurisdiction. While Congress does not have unfettered control over lower court jurisdiction such that it could in effect abolish the courts by obliterating their jurisdiction, it is also clear that some degree of congressional control, consistent with the Constitution, is valid.

Just as the text of Article III is inconclusive in determining. whether Congress may abolish lower federal courts in $1973,{ }^{103}$ it also provides little guidance with respect to the scope of congressional authority over inferior federal court jurisdiction. Article III states that the judicial power shall extend to enumerated classes of cases. ${ }^{104}$ While this might be taken to imply the Congress must give some federal court or courts jurisdiction in all cases outlined in Article III, it is not clear whether vesting discretionary jurisdiction in the Supreme Court to hear all federal cases would satisfy such a requirement.

Article III's silence on the scope of congressional control over the lower federal courts does not mean there is no guidance on the matter. The considerations that underlie the conclusion reached in Part I have jurisdictional implications as well: The federal forums mandated by them must be invested with jurisdiction to hear federal issues. Other constitutional provisions and the manner in which they interact with jurisdictional statutes provide further guidance.

\section{A. Congressional Power to Restrict Jurisdiction to Avoid Case Over- loads and Promote Efficiency}

It is tempting to conclude that Congress must give the lower courts power to hear all cases within the federal judiciary's constitutionally defined jurisdiction. Under such a theory failure by the Federal Ju-

power so as to destroy the Court's essential role in the constitutional scheme. Sec Hart, The Power of Congress to Limit the Jurisdiction of Federal Courts, 66 Harv. L. Rev. 1362 (1953). Compare I M. Crossker, supra note 27, at 616, with Lee, Letters of a Federal Farmer, Letter III (pamphlet originally published Oct. 10, 1787), reprinted in Pamphlets, supra note 30 , at 308 .

The Supreme Court was a vehicle for implementing the accepted policy of having a national judiciary. Whatever Professor Hart based his argument upon-the cornerstone appears to be a separation of powers theory-it is implausible that the Constitution allows Congress to destroy the essence of that which the Court represents, the national judiciary. Professor Hart's thesis therefore suggests that Congress cannot destroy an essential role of the national judiciary. See R. BERGER, supra note 38, at 18-19.

103. See p. 502 supra.

104. U.S. Const, art. III, § 2. 
dicial Code to grant lower federal courts the jurisdiction enumerated in Article III is unconstitutional. There are three principal classes of such cases. A litigant whose federal question or diversity claim involves less than $\$ 10,000$ and does not fit within one of the jurisdictional sections not requiring the $\$ 10,000$ jurisdictional amount has no chance of obtaining a federal forum other than the Supreme Court. ${ }^{105}$ Second, the defendant in a state criminal prosecution will in the normal case be unable to present his federal trial defenses to a lower federal court. Finally, there is a class of cases which arise under the Constitution or laws of the United States as these words are used in the Constitution but do not arise under the Constitution or laws within the statutory grant of federal question jurisdiction. ${ }^{1 \text { "13 }}$ Since Supreme Court review of state decisions is inadequate in today's world to fulfill the national judiciary's role of doing justice in particular cases, these classes of cases suggest that the current jurisdictional scheme is inconsistent with the original goals.

The conclusion on which the foregoing is based, however, is a faulty one. The availability of a federal lower court forum for each case should be sacrificed only when providing such a forum would seriously undermine the judicial system. An overabundance of federal forums with unrestricted jurisdiction to hear all federal cases could in fact undermine the judiciary. A number of factors suggest the necessity for linedrawing. First, the expense of such a system might make it impracticable. ${ }^{107}$ Second, a large increase in the caseload would inevitably mean an increase in the number of judges and a decrease in the prestige attached to being a federal judge. Many commentators, including Judge Friendly, have stated that such prestige is needed if the federal bench is to continue to attract qualified lawyers, especially in areas where private practice is more lucrative. ${ }^{10 s}$ "Any deterioration in the quality of the district judges individually or of their performance collectively would destroy the very values the federal court system is meant to attain." 109

105. For cxample, in Lynch v. Houschold Finance Corp., 405 U.S. 538 (1972), the Court noted that suits against federal officials for alleged deprivations of constitutional rights must satisfy the jurisdictional amount requirement. Id. at 547 . For a complete list of those claims that would necessarily be cognizable under Article III should courts insist on what Judge Friendly calls the "maximum model," see H. Friendey, supra note 37 , at $12-13$.

106. See, e.g., Shoshone Mining Co. v. Ritter, 177 U.S. 505, 506 (1900); Mishkin, The Federal "Question" in the District Courts, 53 Colum. L. Rev. 157, 161-63 (1953).

107. An carly objection to the proposed Constitution was that the "expense of the new plan is terrifying . . Letters of Agrippa, I (Essay originally published in the Mass. Gazette, Nov. 23, 1787), reprinted in Essays, supra note 30, at 54.

108. H. FRIENDLY, supra note 37, at 30 .

109. Id. at 31. See also Frankfurter, Distribution of Judicial Power Between the United States and State Courts, 13 CoRnell L.Q. 499, 515-16 (1928). 
Thus, it would appear that Congress has some Article III authority to limit federal jurisdiction. The authority to curtail, however, is limited by its origins. It cannot be used to restrict jurisdiction over busing, reapportionment, or any other narrowly defined class of cases that pose little threat to efficiency; such selective curtailments would bear no rational relationship to the end sought, namely preservation of the quality of federal justice. The power to curtail is limited to prudent steps which help avoid case overloads.

In practice, the current jurisdictional scheme satisfies the above principles remarkably well. Congress has provided a federal forum for federal questions. ${ }^{110} \mathrm{~A}$ number of important federal rights are covered by specific jurisdictional provisions which eliminate the $\$ 10,000$ jurisdictional requirement. ${ }^{111}$ The cases which fall under the Article III jurisdictional grant but which today receive federal court consideration only on review by the Supreme Court are consistent with the suggested principle. They fall into three main classes: (1) state criminal prosecutions; (2) federal question and diversity cases with less than $\$ 10,000$ in controversy; and (3) those cases in which a federal question may be lurking in the background but which do not arise under the Constitution or laws of the United States within the meaning of 28 U.S.C. $\$ 1331.112$ The first class presents no real difficulty because any state criminal defendant can obtain a federal forum for his federal claims under prevailing federal habeas law. ${ }^{113}$ The second and third classes of cases are potentially'

110. The Supreme Court has on occasion lent impetus to this trend. See Lynch v. Household Finance Corp., 405 U.S. 538 (1972) (eliminating jurisdictional amount requirement in civil rights cases); Fay v. Noia, 372 U.S. 391 (1963) (expanding availability of federal habeas corpus to state prisoners).

111. See, e.g., 28 U.S.C. $\$ \S 1343,1344$ (1970) (civil rights). A more complete list may be found in Batok, supra note 11, at 847-48. See also H. FriendLy, supra note 37, at 12l. Judge Friendly feels that there is no rationality in the classes of cases Congress has chosen to except from the jurisdictional amount requirement. Id. at 122-23. See also C. WRIGHT, FEDERAL CourTs 107-09 (1970).

112. See note 106 supra. By the brief treatment of this class of cases, I do not mean to suggest that they are easily recognizable or explainable. See generally BATOR 850-90.

There is another class of diversity cases in which the full range of constitutional jurisdiction is not vested. 28 U.S.C. $\$ 1332$ (1970), the diversity statute, has been construed to require full diversity in cases involving multiple defendants. 2A MoorL's Federal Practice 8.10 , at 1660-61 (2d ed. 1972). Yet under the rule of State Farm Fire \& Casualty Co. v. Tashire, 386 U.S. 523 (1967), diversity between only two adverse parties satisfies the constitutional diversity requirement. In this class of cases the federal interest is so small that Congress could rationally act to prevent them from clogging the district courts. See note 180 infra.

113. It should be noted that the framers did not contemplate so active a role in state criminal proceedings as the federal courts have taken. They could not, for example, contemplate application of the Bill of Rights to the states. See Barron v. Baltimore, 32 U.S. (7 Pet.) 243 (1833). Therefore, the absence for many years of a federal forum for constitutional claims in state criminal cases is not inconsistent with what we take to be their view of the national judiciary, see F. Frankfurter \& J. Landis, 
so numerous that if Congress were required to create enough federal courts to hear them or to confer such jurisdiction on the existing federal courts, the courts would be swamped or the judiciary would have to be expanded to a dangerous extent. ${ }^{114}$

The restrictions in all three classes of cases have additional characteristics which make them acceptable devices for limiting federal jurisdiction. The $\$ 10,000$ jurisdictional requirement is, in an important sense, a neutral scheme of jurisdictional withdrawal. It would not seem to prevent the lower federal system from hearing any particular federal issue and thus avoids the possibility of substantive lawmaking by jurisdictional manipulation. ${ }^{115}$ There is a difference in kind between limiting the amount in controversy without regard to subject matter and foreclosing jurisdiction to hear, for example, desegregation actions. The latter has the immediate effect of relegating consideration of a particular federal question to state courts and the remote possibility of Supreme Court review. Thus lack of jurisdiction with respect to some federal question cases cannot justify limiting federal jurisdiction with respect to particular issues.

Federal question and diversity cases involving less than $\$ 10,000$ and lurking federal question cases arguably involve less vital federal interests as classes of cases than do other potential areas for jurisdiction restriction. ${ }^{110}$ The third class, involving as it does cases in which a federal question may be lurking but does not arise under the Constitution or laws of the United States within the meaning of 28 U.S.C. $\$ 1331$, should be restricted for the same reasons that the abstention doctrine is permissibly employed. That is to say, until the federal question has become clear the federal courts can avoid what is essentially a matter within the responsibility of the state courts.

There is a similar ground on which the failure to extend district court jurisdiction in another class of cases can be justified. In state

supra note 60 , at 109 , for, although federal forums must be available to vindicate federal rights, those rights that are of federal or constitutional cognizance may of course change over time. Modern federal habeas doctrine makes federal forums available for state prisoner's' constitutional claims.

114. As to the potentially enormous number of cases in the "lurking" federal question class of cases, sec Mishkin, supra note 106, at 162 . The jurisdictional amount limit has been the traditional method of keeping dockets uncluttered. See B.rTor, supra note 11 , at $847 \cdot 49$; F. FRANkFurTer \& J. LANDIS, supra note 60 , at 93-94, 139.

115. See pp. 523-25 infra.

116. Note, Federal Jurisdictional Amount: Determination of the Matter in Controversy, 73 HaRv. L. REv. 1969 (1960). This Note analogizes the jurisdictional amount to a small claims exemption. It argues that such a restriction allows the "federal courts to devote adequate attention to 'important' matters by keeping small claims off the dockets." Id. 
criminal proceedings it is often not clear at the outset whether a federal question will be involved. Sometimes a federal question does not become apparent until the defense has coalesced and even then it may be difficult to determine whether the "federal" matter will determine the outcome. Unless it does even the Supreme Court could not overturn a conviction. ${ }^{117}$ To require original federal jurisdiction in all these cases would be extremely wasteful. The state courts here perform a useful sifting function by narrowing the class of cases that require federal review to those that in fact turn upon federal issues.

Thus the $\$ 10,000$ jurisdictional amount limit in federal question and diversity cases, which was enacted to relieve the burden on the federal courts, ${ }^{118}$ is a constitutional exercise of congressional authority. Similarly, congressional refusal to extend federal question jurisdiction to all cases in which the Constitution might authorize it can be viewed as preserving the federal courts' essential role by not extending their reach to a ruinous number of cases. The salient features of these current restrictions are neutrality, efficiency, and some weighing of interests. They provide useful guidelines for Congress' exercise of its power to protect the courts. For instance, the legitimate end of efficiency may be served by a limiting statute without undue sacrifice of what should be the dominant theme in the jurisdictional structure-federal court availability. Nevertheless, adherence to any one goal does not ensure that a given jurisdictional restriction will be proper. There is a limit to how far Congress can go in the name of efficiency. A provision precluding federal court jurisdiction in all federal question cases would have a dramatic impact on caseloads, but the cost in terms of availability would be too great. Nor will "neutrality" always guarantee propriety. A statute excluding every second case filed in district court would, of course, reduce caseloads and achieve total neutrality-every issue would eventually be heard in federal court. Its failure to assess the importance of the interests involved, however, would render it so arbitrary as surely to be unconstitutional.

\section{B. Congressional Power to Curtail Jurisdiction Because of Sub- stantive Disagreement With Judicial Decisions}

The jurisdictional limitations thus far considered are different from those mentioned at the outset of this article. The proposed statutes

117. See Minnesota v. National Tea Co., 309 U.S. 551 (1940); Murdock v. Memphis, 87 U.S. (20 Wall.) 590 (1875).

118. See BATOR, supra note 11 , at 3940 . 
restricting jurisdiction over reapportionment, desegregation, and busing cases have little in common with the $\$ 10,000$ jurisdictional requirement. They were inspired by something other than regard for judicial efficiency. As these examples suggest, in practice it has not been difficult to distinguish legislation motivated by efficiency considerations from political reaction. ${ }^{119}$ Sponsors could not seriously emphasize the beneficial effect of busing curbs on overcrowded dockets. Such proposals are frank attempts to alter or neutralize substantive federal decisions, ${ }^{120}$ motives which on one occasion arguably led the Court to strike down a jurisdictional statute. ${ }^{121}$ These proposed statutes focus directly on a controversial area. Because of their narrow scope the considerations that warrant permitting Congress broad

119. In an earlier confrontation between branches of government, the Senate Judiciary Committee chastized President Roosevelt for attempting to "pack" the Supreme Court under the guise of adding judges to increase court efficiency. S. REP. No. 711, 75th Cong., Ist Sess. (1937).

120. Sponsors have not masked their intentions. Consider Senator Jenner's remarks on why he introduced legislation to restrict the Supreme Court's jurisdiction in subversive activity cases, supra note 8:

It was introduced because I had become gravely concerned by what appeared to

be the self-evident fact that we had a runaway Supreme Court to deal with.

....

[ $\dot{T}]$ hère had been a long line of cases, involving Communists and subversive activity, in which the Court had accepted, point after point, the legal propositions advanced by the Communists, until we arrived at a point where it seemed to me Congressional action was inescapably required.

.....

Accordingly, I drafted a bill to withdraw appellate jurisdiction from the Supreme Court ....

104 Conc. REc. 18635, 18636 (1958). Senator Butler, who proposed an amendment to the Jenner Bill, explained his reasons as follows:

[The] proposed legislation ... is before the Senate because the people of this country are greatly troubled and widely dissatisfied with the results of a series of decisions by the Supreme Court of the United States which have gone beyond the Court's proper sphere....

Id. at 18646 .

Sponsors of the Tuck Bill, supra note 10, were no less candid. Senator Thurmond, who introduced the bill in the Senate, was concerned solely with the consequences of the reapportionment decisions:

[T] $T$ here is a necessity for urgent action on this question. Almost all of the States of the Union can be reconstructed by judicial fiat if these decisions are implemented across the board. The resulting chaos would be detrimental to the continuance of sound governmental practices in these States.

110 CoNG. REC. 22097 (1964). His co-sponsors were equally unconcerned with promoting efficiency:

The Supreme Court, by entering into the political field of the internal organization of the States, has engaged in changing the Constitution by usurpation.

Id. at 22098 (Sen. Robertson). See also id. at 22101-02 (Sen. Stennis).

Senator Ervin, chice spokesman for passage of $\$ 702(a)$ of Title II of the Omnibus Crime Control Act (see note 123 infra), which would have withheld federal habeas relief from state prisoners, explained that that provision was designed to eliminate dilatory habeas petitions and to maintain the independence of state criminal justice. 114 CONG. REC. 14182 (1968).

Finally, President Nixon's busing bills, supra note 13, were designed to "place firm and effective curbs on busing." MEsSAge From the President of THE UNITEd STATES ReLa. ine to Busing aid Equality of Educational Opportunity, and Transmitting a Draft of Projosen Legislation to Impose a Moratorium on New and Additional Student 'Trivslortatiox, H.R. Doc. No. 92-195, 92d Cong., 2d Sess. (1972).

121. United States v. Klein, 80 U.S. (13 Wall.) 128 (1872). See pp. 525-31 infra. 
discretion to avoid case overloads are no longer controlling. As the subject matter of a statute narrows, the logistical stakes involved in conferring or denying federal jurisdiction diminish. The quality, efficiency, and expense of a judiciary are always relevant considerations, but in the context of most of these statutes their weight is de minimis. ${ }^{122}$

While many previously proposed statutes are easily characterized as neutral or substantive, there is, of course, no clear line between the two kinds of jurisdictional statutes. ${ }^{123} \mathrm{~A}$ useful approach for

122. It is true that the busing cases have consumed and continue to consume an enormous amount of judicial time and resources. H. FRIENDLY, supra note 37, at 18-19. I would argue that a statute which based a curtailment of jurisdiction to hear desegregation cases upon the advantages of such a move in terms of court dockets would fail because the primary motive was transparent and impermissible. For discussions of the difficulties connected with testing a statute's constitutionality by a determination of the motives behind its enactment see. Brest, Palmer $v$. Thompson: An Approach to the Problem of Unconstitutional Legislative Motive, 1971 SUP. CT. REv. 95; Ely, Legislative and Administrative Motivation in Constitutional Law, 79 YALE L.J. 1205 (1970). Professor Ely argues that, while in most situations where government action is challenged considerations of motive should play no part in a court's decision, there is a class of cases where inquiry about motive is appropriate. In speaking about federal jurisdictional statutes Professor Ely says:

If a statute denying jurisdiction in a certain class of cases can be shown to be the product of a desire by a majority of those voting for it to deny citizens the protection of a certain constitutional right, the court should insist upon a defense of the choice in terms which rationally relate the choice to an acceptable goal and are unrelated to the inhibition of the right in issue. It would be impossible to infer such a forbidden motivation from the setting of a jurisdictional amount applicable to all sorts of cases. An inference of unconstitutional motivation might, moreover, on rare occasion be rebutted by a showing that some adequate alternative means of ensuring protection of the right exists, and Congress knew of it. But where the inference of intent to curtail the enforcement of a constitutionally guaranteed right is solid, and no alternative legitimate justification suggests itself and one seldom would-the Court should invalidate the statute, "jurisdictional" though it may be.

Id. at 1308-09 (footnotes omitted).

123. It is possible to imagine a law that falls neatly into both categories. A single statute might deal with many different categories of cases. No such jurisdictional provision has been found. Another is a statute dealing with federal habeas corpus cases for state prisoners, a class of cases with some substantive unity but large enough to have a substantial impact on lower court caseloads. See H. Friendiy, supra note 37, at 18 . As mentioned before, $\S 702(a)$ of Title II of the Omnibus Crime Control and Safe Streets bill, S. 917, 90th Cong., 2d Sess. (1968), would have terminated federal habeas corpus for state prisoners:

The judgment of a court of a State upon a plea or verdict of guilty in a criminal action shall be conclusive with respect to all questions of law or fact which were determined, or which could have been determined, in that action until such judgment is reversed, vacated, or modified by a court having jurisdiction to review by appeal or certiorari such judgment; and neither the Supreme Court nor any inferior court ordained and established by Congress under article III of the Constitution of the United States shall have jurisdiction to reverse, vacate, or modify any such judgment of a State court except upon appeal from, or writ of certiorari granted to review, a determination made with respect to such judgment upon review thereof by the highest court of that State having jurisdiction to review such judgment.

This Section was eliminated by the Senate. 114 Cong. REc. 14171-81 (1968).

Such a provision must be analyzed not only in terms of Congress' jurisdictional power, but also in relation to Article $I, \$ 9$, of the Constitution, which prohibits suspension of the writ of habeas corpus except in emergencies. See Eisenstrager v. Forrestal, 174 F.2d 961 (D.C. Cir. 1949). See also Fay v. Noia, 372 U.S. 391, 405.06 (1963). 
dealing with such statutes is to consider jurisdictional statutes on a continuous spectrum. At one end are clear efforts to promote efficiency and avoid case overloads. Such statutes should be judged largely by the factors already discussed. At the other end are blatant efforts to alter or reduce the impact of judicial results. The considerations underlying a presumption of validity at the efficiency end are of greatly decreased relevance at what may be called the spectrum's substantive end. At this substantive end the presumption that there must be forums for federal issues would weigh strongly against restrictive jurisdictional statutes.

With this last presumption favoring federal forums as a guiding principle, one may ascertain the scope of Congress' substantive jurisdictional power by employing traditional statutory analysis. In passing on the validity of a federal statute one must determine its natural or probable effect and measure that effect against constitutional requirements. If a statute fails to conform to those requirements it must fall. The foregoing principles apply, of course, to jurisdictional statutes, ${ }^{124}$ but because jurisdictional statutes seem to have a less direct substantive impact than other statutes, some preliminary analysis of the effects of jurisdictional statutes is in order.

The impact of a statute depriving both federal and state courts of jurisdiction to hear a claim is obvious and drastic. Statutes that foreclose only lower federal court jurisdiction have more subtle ${ }^{125}$ but no less serious substantive effects. Consider a statute that deprives lower federal courts, but not state courts, of jurisdiction to hear a narrowly defined class of cases. Such a provision cannot be justified, as some would claim, ${ }^{126}$ on the ground that inferior federal jurisdiction is not really necessary to vindicate federal rights because of the availability of Supreme Court review of state court decisions. The volume of cases would render Supreme Court review an illusion on all but a few substantive issues. It is unreasonable to expect that the Court could vindicate federal rights for all litigants or even classes of litigants who would seek review from it. ${ }^{127}$

124. See pp. 523-27 infra.

125. In 1964, Congressman McCulloch argued that withdrawal of federal jurisdiction in apportionment cases did not threaten to deprive individuals of constitutional rights "because of the availability of State courts for redress . . ." 110 CoNG. REc. 20250 (1964). The Nixon busing bills also leave unaffected state court jurisdiction. Note, supra note 12, at 1553. For a response to Congressman McCulloch's argument, see text accompanying notes $126-27$ and pp. 522-23 infra.

126. See Hart, supra note 102, at 1401; cf. Ex parte Royall, 117 U.S. 24I, 248 (1886); Hill, supra note 14, at $1117-18$ (state courts are available to grant remedies for constitutional rights in the absence of federal courts).

127. The Civil Rights Removal statute, 28 U.S.C. $\$ 1443$ (1970), is an indication that in some cases Congress feels Supreme Court review is not adequate to secure federal rights. 
Furthermore, in cases in which state courts uphold the validity of federal statutes, appeal to the Supreme Court is not as of right. ${ }^{128}$ Even if the Court were physically capable of handling all of these cases, there could be no guarantee to the parties that their federal claims would ever be heard in a federal forum. Cases in which appeal is supposedly as of right do not necessarily receive consideration on the merits. The Court's practice of dismissing for want of a substantial federal question ${ }^{129}$ makes its control over its appellate docket similar to its control over its certiorari docket. ${ }^{130}$ Although the two classes of cases may not receive identical treatment, ${ }^{131}$ it is certainly true that no particular litigant with a "right" of appeal to the Court has any assurance that the Court will hear the merits of his case. ${ }^{132}$ Thus exercise by Congress of broad jurisdictional power based on the existence of state courts is not consistent with the Article III role of the national judiciary.

It is not enough to say that state courts might perform well or that the Supreme Court might grant certiorari or that the lower federal courts might not be up to the task of protecting federal rights. These results may all occur with some frequency. The crux of the argument is independent of state court performance. The job is given by Article III to the national judiciary. The framers undoubtedly realized that in some cases state courts could suffice, but they chose to rely on independent and tenured federal judges for the vindication of federal rights. 133

A second effect of a statute depriving lower federal courts of jurisdiction in federal cases is related to the fact that the Supreme Court

128. 28 U.S.C. $\$ 1257$ (1970). Appeal is of right only where a federal statute is held unconstitutional by a state court.

129. See, e.g., Zucht v. King, 260 U.S. 174 (1922).

130. See Frankfurter \& Landis, The Business of the Supreme Court at October Term, 1929, 44 Harv. L. Rev. 1, 12-14 (1930); Wiener, The Supreme Court's New Rules, 68 HARv. L. Rev. 20, 51 (1954) (quoting Chief Justice Warren).

131. See Bator, supra note 11 , at 649; H. Hart \& H. Wechsler, The Federul Courts \& THE FEDERAL SYSTEM 5 $54-75$ (1953).

132. See, e.g., Frankfurter \& Landis, supra note 130, at 12-14. But see Butor, supra note 11 , at 649 .

133. In 1789 Oliver Ellsworth noted possible difficulties in relying on state courts for the protection of federal claims. "To annex to State Courts jurisdictions which they had not before, as of admiralty cases, and, perhaps, of offences against the United States, would be constituting the judges of them, pro tanto, federal judges, and of course they would continue such during good behavior, and on fixed salaries, which in many cases would illy comport with their present tenure of office." Letter from Ellsworth to Judge Richard Law, dated August 4, 1789, quoted in W. Brown, Tirr LIFE OF OLIVER ELLSwORTH $189-90$ (1905). Although Ellsworth mentions expressly only admiralty and federal criminal cases, his point is also applicable to constitutional claims not previously cognizable in state courts. Were Congress to attempt to abolisl federal jurisdiction in large classes of cases, or perhaps in any case of constitutional dimension where no realistic federal review were available, careful scrutiny based on Ellsworth's view would be necessary. 
cannot review each case. In the case of an individual whose federal claim is rejected by state courts and who, because the Court is unable to hear all cases, fails to gain Supreme Court review, the effect of a federal jurisdictional withdrawal may be indistinguishable from that of a substantive statute foreclosing his claim. Technical niceties, of course, could be employed to distinguish the two kinds of laws. Jurisdictional statutes are theoretically unrelated to primary behavior; they impose no direct duties or penalties. The fact that a law appears in the jurisdictional section of the United States Code, however, does not mean that it lacks substantive impact. Thus, where constitutional rights are rendered nugatory by state courts, ${ }^{134}$ the effect of a federal jurisdictional limitation on an individual denied Supreme Court review is strikingly close to a substantive law limitation. ${ }^{135}$ Indeed, this effect is the very reason for congressional attempts to curtail jurisdiction. ${ }^{136}$ Any substantive statute with such deleterious effects on the enforcement of federal rights would be struck down. ${ }^{137}$ Jurisdictional statutes should receive similar scrutiny. They too are subject to constitutional limitations; ${ }^{138}$ if they have such unconstitutional substantive effects, they are themselves unconstitutional.

The proposition that Congress may not accomplish by jurisdictional manipulation that which it could not otherwise accomplish was endorsed in two decisions rendered after Congress had foreclosed state and federal jurisdiction to hear the particular claims involved. In Battaglia v. General Motors Corp. ${ }^{138}$ plaintiffs sued under the

134. Two examples are the wholly inadequate response of Mississippi courts to claims by civil rights workers, documented in Amsterdam, Criminal Prosecutions Affecting Federally Guaranteed Rights: Federal Removal and Habeas Corpus Jurisdiction to Abort State Court Trial, 113 U. PA. L. REv. 793 (1965), and state efforts to harass the NAACP by use of official authority, including the courts. See J. Peltason, FifTy-EIGHT LONELY MEN 65-72 (1961). See also Bator, Finality in Criminal Law and Federal Habeas Corpus for State Prisoners, 76 HARv. L. REv. 441, 510 (1963); Reitz, supra note 80, at 487 .

135. Even in areas of high visibility, such as segregation, reliance on Supreme Court review to protect federal rights is misplaced; cf. Naim v. Naim, 350 U.S. 891 (1955); 350 U.S. 985 (1956). The Supreme Court's departure from its initial function of vindicating individual claims renders too uncertain the availability of review in any particular case. Even when the Court does act the delay endemic in appellate review means that a victory will often come too late. See J. Peltason, supra note 134, at 76-77; Amsterdam, supra note 134, at 798.

136. See note 120 supra.

137. Cf. Green v. New Kent County School Bd., 391 U.S. 430 (1968) (freedom of choice plan); Griffin v. County School Bd., 377 U.S. 218 (1964) (public support of private segregation academies); Hall v. St. Helena Parish School Bd., 197 F. Supp. 649 (E.D. La. 1961), aff'd mem., 368 U.S. 515 (1962); cases cited in Note, Segregation. Academies and State Action, 82 YALE L.J. 1436, 1440 nn.34-35 (1973).

138. See pp. 525-26 infra.

139. 169 F.2d 254 (2d Cir. 1948). 
Fair Labor Standards Act, ${ }^{140}$ seeking compensation for time spent cleaning up after their work days. The Act provides for compensation at time and a half the normal wage for that part of a work week in excess of 40 hours. The Supreme Court had previously held that the term "work week" in the Act included the periods of time for which plaintiffs sought compensation. ${ }^{141}$ Congress, fearing drastic unexpected liability for employers as a result of the Supreme Court decisions, ${ }^{142}$ enacted the Portal-to-Portal Act of $1947,{ }^{143}$ which in effect overruled the Supreme Court's interpretation of "work week" and deprived federal and state courts of jurisdiction to enforce the unanticipated liability under the Fair Labor Standards Act. ${ }^{144}$ Plaintiffs claimed that the Portal-to-Portal Act, which was made retroactive, violated the Fifth Amendment's due process clause by destroying rights recognized previously by the Supreme Court. The Battaglia court rejected the substantive claim on the merits ${ }^{145}$ but did not feel that the outcome was governed by the jurisdictional removal. If plaintiffs' substantive claim had been upheld, the jurisdictional limitation would not have prevented the court from reaching the merits. ${ }^{145}$ Congress could not accomplish by a jurisdictional limitation what it could not accomplish by substantive regulation. ${ }^{147}$ The substantive impact of the jurisdictional statute in Battaglia was beyond question. If, as argued above, statutes foreclosing only lower federal court jurisdiction have substantive impact, then the reasoning in Battaglia applies to such laws.

The Emergency Price Control Act of $1942^{148}$ is the second instance of a congressional attempt to withdraw certain claims from federal and state courts. The Act deprived existing federal and state courts $^{149}$ of jurisdiction to consider the validity of price regulations promulgated under it and to restrain or enjoin enforcement of those regulations. ${ }^{150}$ The regulations could be attacked only in a new

140. Act of June 25, 1938, Pub. L. No. 718, 52 Stat. 1060 (codified at 29 U.S.C. $\$ \S 201-19$ (1970)).

141. Anderson v. Mount Clemens Pottery Co., 328 U.S. 680 (1946); Jewell Ridge Corp. v. Local No. 6167, 325 U.S. 161 (1945); Tennessee Coal Co. v. Muscoda Local, 321 U.S. 590 (1944).

142. See BATOR, supra note 11 , at 322-23.

143. 29 U.S.C. $\$ \$ 251-62(1970)$.

144. Id. at $\$ 252(\mathrm{~d})$.

145. See also Thomas v. Carnegie-Illinois Steel Corp., 174 F.2d 711 (3d Cir. 1949).

146. 169 F.2d at 257.

147. Judge Chase wrote in his decision for the Second Circuit: "We think, however, that the exercise by Congress of its control over jurisdiction is subject to compliance with at least the requirements of the Fifth Amendment." Id.

148. Act of Jan. 30,1942 , ch. 26,56 Stat. 23.

149. Id. at $\$ 204(\mathrm{~d})$.

150. Id. 
Emergency Court of Appeals, created by the Act, the decisions of which could be reviewed by the Supreme Court on petition for writ of certiorari. ${ }^{151}$

Under provisions of the Act a district court convicted Yakus of violating price regulations, rejecting his defense based on their alleged invalidity. In affirming the conviction, ${ }^{152}$ the Supreme Court held that there was no right to injunctive relief under the circumstances because the procedure for protest and review in the Emergency Court of Appeals "affords to those affected a reasonable opportunity to be heard and to present evidence."153 The Court emphasized the adequacy of the separate procedure ${ }^{154}$ and intimated that, in the absence of an adequate substitute, the statute under review might be vulnerable.155

Additional support for subjecting jurisdictional statutes to constitutional scrutiny comes from United States $v$. Klein. ${ }^{150}$ Klein was administrator of the estate of a decedent whose cotton had been sold by the Union during the Civil War. He sued the United States in the Court of Claims under the Abandoned and Captured Property $\mathrm{Act}^{157}$ for the value of the lost property. Federal legislation afforded such a right of action to those who had never given any aid or comfort to the Confederacy. ${ }^{158}$ In United States $v$. Padelford, ${ }^{159}$ the Supreme Court had held that a presidential pardon, such as the one obtained by Klein's decedent, was conclusive proof that the claimant did not engage in the rebellion. Based on Padelford, the Court of Claims granted Klein relief. While the government's appeal from the decision was pending in the Supreme Court, Congress, re-

151. A party contesting a price regulation under the Act could file a protest with the Price Administrator. Id. at $\$ 203($ a). If the protest was denied a complaint could be filed with the Emergency Court of Appeals. Id. at $\$ 204(a)$.

152. Yakus v. United States, 321 U.S. 414 (1944).

153. Id. at 433 .

154. Id. at 444 .

155. Id. at 446. In discussing the facts in Yakus the Court noted that penal consequences could flow from departures from the rate schedule set by the Interstate Commerce Commission and that the defendant in the criminal proceeding could not raise the question of the reasonableness of the rates as a defense. Id. at 445-46. The Court felt that such a limitation was unquestionably valid and went on to say: "As we have pointed out such a requirement is objectionable only if by statutory command or in operation it will deny, to those charged with violations, an adequate opportunity to be heard on the question of validity. And, as we have seen, petitioners fail to show that such is the necessary effect of the present statute, or that if so applied as to deprive them of an adequate opportunity to establish the invalidity of a regulation there would not be adequate means of securing appropriate judicial relief in the course either of the statutory proceeding or of the criminal trial." Id.

156. 80 U.S. (13 Wall.) 128 (1872).

157. Act of March 3, 1863, ch. 120, 12 Stat. 820.

158. Id.

159. 76 U.S. (9 Wall.) 531 (1870). 
acting to Padelford, enacted a statute declaring pardons inadmissible and depriving the Supreme Court of jurisdiction to hear a case in which the claimant proved loyalty by use of a presidential pardon. ${ }^{100}$ The Court held the withdrawal of jurisdiction unconstitutional.

The rationale underlying Klein is not clear. The holding is frequently interpreted to be that Congress cannot "prescribe rules of decision to the Judicial Department" in pending cases. ${ }^{161}$ Such a view cannot easily be reconciled with the well-established principle that appellate courts are obliged to follow changes in the law enacted during the pendency of an appeal, ${ }^{162}$ a principle which would seem to apply with full force to an otherwise valid jurisdictional limitation. ${ }^{163}$. There is also language in the opinion suggesting that a crucial aspect of the case was the fact that the United States was a party and that it is particularly offensive for a litigant to prescribe a rule of decision for its own case. ${ }^{104}$ Yet in many instances the doctrine of sovereign immunity allows the United States to decide whether it will be subject to suit at all. Klein's was just such a case because he based his cause of action on an act of Congress. More to the point, on at least one occasion the Court has upheld Congress' repeal of a statute authorizing an action against the United States after the case had been decided by the Court of Claims and while an appeal to the Supreme Court was pending. ${ }^{105}$ Perhaps the safest reading of Klein is that it precludes Congress from impairing

160. The statute was enacted as a rider on an appropriation bill. Act of July 12 , 1870,16 Stat. 235.

161. Note, supra note 12 , at 1556-57, quoting 80 U.S. at 146. See Ratner, supra note 15 , at 181 (" $[\mathrm{T}]$ he constitutional principle ... asserted [in Klein] would preclude any congressional attempt to control the decision in a particular case through the guise of a jurisdictional limitation . . . ."); Note, Moratorium on School Busing for the Purpose of Achieving Racial Balance: A New Chapter in Congressional Court-Curbing, 48 Notre DAME LAWYER 208, 229 (Klein precludes congressional control of a particular case). Note in this regard that the compromise jurisdictional provision in the recently enacted Alaska Pipeline Bill specifically exempts from the jurisdictional withdrawal all constitutional questions. Section 203(d) of Title II says in pertinent part:

The actions taken pursuant to this title ... shall be taken without further action

under [NEPA] .... and the actions of Federal officers [in furtherance of this Act] .. shall not be subject to judicial review under any law except that claims alleging the invalidity of this section may be brought within sixty days following its enactment, and claims alleging that an action will deny rights under the Constitution of the United States ... may be brought within sixty days following the date of such action.

Pub. L. No. 93-153, $\$ 203$ (d) (Nov. 16, 1973), reprinted in 42 U.S.L.W. 21 (Statutes: Dec. 4,1973 ). See N.Y. Times, Nov. 17, 1973, at 1, col. 4 .

162. See District of Columbia v. Eslin, 183 U.S. 62 (1901); BAToR, supra note 11, at $316 \mathrm{n} .4$ \& cases cited therein.

163. See District of Columbia v. Eslin, 183 U.S. 62 (1901), in which the Court dismissed, for want of jurisdiction, an appeal from a Court of Claims decision where, during the pendency of the appeal, Congress repealed the act under which the action had been brought.

164. 80 U.S. at 146 ("Can we [dismiss the appeal] without allowing one party to the controversy to decide in its own favor?"). See Ratner, supra note 15, at 181 .

165. District of Columbia v. Eslin, 183 U.S. 62 (1901). 
the Executive's power to pardon. ${ }^{106}$ In any event, the Court did find a jurisdictional statute unconstitutional and that alone demonstrates that such laws are subject to constitutional limitation. ${ }^{107}$

Thus, it is clear that jurisdictional statutes are subject to constitutional limitations. This, in turn, provides a basis for measuring such statutes in terms of their substantive impact-the procedure followed in Yakus and Battaglia. When their effect is to abrogate constitutional rights, they are no more valid than any other statute violating the Constitution.

The corollary of the foregoing is that Congress has unfettered power to enact jurisdictional laws that accomplish what it could have accomplished by means of a substantive rule; that is, it may enact any jurisdictional statute that does not prevent vindication of a constitutional right. In cases in which Congress can constitutionally prescribe a rule of decision, no federal right that could be vindicated under a constitutional claim can be excluded from the federal courts by the withdrawal of jurisdiction. ${ }^{18 s}$ In short, Congress can withdraw

166. 80 U.S. at 147. See BATor, supra note 11, at 315; Note, supra note 12, at 1557; U.S. Consr. art. II, $\$ 2$. This is the only specific ground of decision mentioned by Professor Fairman. C. Fairman, 6 History of the Supreme Court of the UNited States: RECONSTRUCTION AND REUNION 845 (1971).

Bator et al. note another flaw found by the Court. "[I]n forbidding the court "to give the effect to evidence which, in its own judgment, such evidence should have' and directing the court 'to give it an effect precisely contrary;' 'Congress has inadvertently passed the limit which separates the legislative from the judicial power ... BATOR 315 (quoting Klein). The second part of the quotation is of course merely a conclusion and offers no support for the holding. The first part is open to the objection made in the text, see p. 526 supra, that Congress may change the law pending appeal.

167. Note, supra note 12 , at 1557 , states that Klein merely "suggests" such a conclusion. An actual holding of unconstitutionality appears to be more than a suggestion. In light of the ambiguities surrounding the Court's opinion already noted in the text, however. a cautious reading of the case is appropriate. But cf. Yakus v. United States, 321 U.S. 414,443 (1944) (Congress' jurisdictional power is "subject to other constitutional limitations.").

168. Congress' power to waive jurisdiction of parties who have obtained it collusively is another instance where no constitutional right is sacrificed by a jurisdictional limitation. No federal interest is lost when jurisdiction is not extended to parties who have, in their exuberance to obtain a federal forum, exceeded the spirit of the Constitution's jurisdictional grant.

Sheldon v. Sill, 49 U.S. (8 How.) 441 (1850), one of the early cases to allow a restriction of federal jurisdiction, upheld a statute that deprived the old circuit courts of jurisdiction to hear "any suit to recover the contents of any promissory note or other chose in action, in favor of an assignee, unless a suit might have been prosecuted in such court to recover the contents, if no assignment had been made, except in cases of forcign bills of exchange." 49 U.S. at 441 . The statute was designed to prevent collusive federal suits. BATor, supra note 11 , at 34 . Perhaps it should have been construed to apply only where collusion was found (It was not. H. HART \& $H$. WECHSLER, supra note 131, at 39, 918), but it has since been redrafted to apply only in proven cases of collusion. 28 U.S.C. $\$ 1359(1970)$.

Although on its facts a state court judgment in sheldon would not have been reviewable in the Supreme Court, BATOR 315, had any constitutional rights been at stake, the Judiciary Act would have permitted review. Judiciary Act of $1789, \S 25$, I Stat. 73,85 . At the time of Sheldon Supreme Court review was probably still adequate as the sole mechanism for vindication of federal rights. The caseload of the Court in 1850 was about 250 cases. F. Frankfurter \& J. LANDIs, supra note 60, at 60. The 
jurisdiction from all cases except those in which a particular outcome is mandated by the Constitution. ${ }^{109}$

The above explains why the Norris-LaGuardia Act ${ }^{170}$ is valid. That Act severely restricts the jurisdiction of the federal courts to issue injunctions or temporary restraining orders in labor disputes. It therefore limits the remedies available to an aggrieved party. ${ }^{171}$ All other state and federal remedies, however, remain available. As long as an injunction is not constitutionally required, ${ }^{172}$ Congress may deprive a federal court of jurisdiction to issue it. In those labor cases where the Constitution may compel injunctive relief, the NorrisLaGuardia Act probably permits it. ${ }^{173}$ The Norris-LaGuardia Act can thus be sustained because what Congress accomplished with a jurisdictional statute could permissibly have been accomplished with a substantive rule. That is, Congress could have declared that the circumstances enumerated in the injunction clause must be found to prevail before a party would have a right to an injunction in a labor dispute. Such a law would have had the same effect as the rule denying federal courts jurisdiction to do otherwise. Such a jurisdictional restriction does not deprive anyone of a federal "right" because Congress could have restricted the remedy by substantive regulation.

Congress phrased the Norris-LaGuardia Act in jurisdictional terms

Court's docket seems to have outgrown the capacities of nine men around 1870. Id. At the time of Sheldon, therefore, lower courts with broad jurisdiction may not have been necessary to ensure vindication of all federal rights.

My thesis does suggest that from the time the Supreme Court's docket became unmanageable until the time federal question jurisdiction was granted to the lower federal courts, the system was unconstitutional. This was, however, a brief period, if it existed at all. For at about the time the Court's docket became too large for it to handle, Congress gave the lower courts a broad federal question jurisdictional grant. Act of May 31, 1870, $\$ 8,16$ Stat. 140, 142; Act of March 3, 1875, 18 Stat. 420. The federalists had been only temporarily successful in conferring broad federal ques. tion jurisdiction. Act of Feb. 13, 1801, 2 Stat. 89. That provision was repealed when Jefferson came to power. Act of March 8, 1802, 2 Stat. 132.

169. Professor Hart suggested using this principle when plaintiffs complain of extra-judicial governmental coercion-action by government officials against private persons or private property. Of jurisdictional restrictions in connection with such programs, he states: "[T] he validity of the jurisdictional limitation depends on the validity of the program itself ...." Hart, supra note 102, at 1387. Hart's limitation to coercive government programs is unduly restrictive, for the principle logically applies in other circumstances. If, for example, in the Portal-to-Portal cases, which involved noncoercive legislation, the due process clause had been held violated, it would make no difference in analyzing the jurisdictional statute that the legislation was noncoercive.

170. 29 U.S.C. $\$ \S 101-15(1970)$.

171. See F. Frankfurter \& N. Greene, The Labor Injunction 220 (1928); Note, supra note 12 , at 1549 .

172. For a discussion of constitutionally mandated remedies see pp. 530-32 infra.

173. Section 7 of the Act allows a court after factfinding to issue injunctions if (l) unlawful acts have been threatened, will be or have been committed and will continue; (2) substantial and irreparable injury will result; (3) greater injury will result to complainant by denial of relief than to defendants by granting; (4) there is no adequate remedy at law; and (5) the public officers charged with protecting complainants are unwilling or unable to do so. 29 U.S.C. $\$ 107$ (1970). It is my view that this provision probably covers all cases in which an injunction may be constitutionally compelled. For instances where injunctions have been allowed, see BATOR, supra note 11, at 317 n.5. 
to avoid an apparent conflict with earlier Supreme Court cases. In Truax v. Corrigan ${ }^{174}$ the Supreme Court struck down, as a denial of due process, a state statute limiting employers' remedies in a fashion similar to the limitation in the Norris-LaGuardia Act. Because it is highly unlikely that Truax would be decided the same way today, ${ }^{175}$ there is little current constitutional difficulty with the NorrisLaGuardia Act. Its restriction on jurisdiction does not deny anyone an otherwise obtainable constitutional right.

The decision that upheld the Norris-LaGuardia Act, Lauf v. E.G. Shinner \& Co., ${ }^{176}$ contains some broad dicta ${ }^{177}$ with respect to the authority of Congress to regulate the jurisdiction of federal courts. Although Lauf is not a great problem today because the substantive rules of the Norris-LaGuardia Act are clearly constitutional, it can be explained. Lauf's holding, as opposed to its broad dicta, would present no problem if, at the time it was decided, Truax was already discredited, for then the Norris-LaGuardia Act would merely have the effect of accomplishing through jurisdiction what Congress could do through substantive rulemaking. By the time Lauf was decided, Truax was already in peril; substantive due process, the approach employed in Truax, saw its demise the year before. ${ }^{178}$ Therefore, although the Lauf court did not have to reach the substantive issue of the validity of the district court injunction because it upheld the withdrawal of jurisdiction, the Court would have upheld as well a substantive rule having the same effect as withdrawal of jurisdiction.

Congress' ability to limit federal court jurisdiction is in part an outgrowth of its general lawmaking power as set forth in Article I of the Constitution. This power, under steady expansion since $M c$ Culloch v. Maryland, ${ }^{179}$ enables Congress to create, refine, and repeal an enormous array of federal rights. Congress' authority to cur-

174. 257 U.S. 312 (1924).

175. See text accompanying note 178 infra.

176. 303 U.S. 323 (1938).

177. The precise words of the Court were: "There can be no question of the power of Congress thus to define and limit the jurisdiction of the inferior courts of the United States." Id. at 330. The majority opinion failed to mention Truax, and thus to overrule it, but that the case was in the Court's mind is shown by the dissenting opinion of Justice Butler. Id. at 332.

178. See E. Barrett, P. Bruton \& J. Honnold, Constitutional Law 670 (1968); R. McCloskey, The Modern Supreme Court 23 (1972). The Court's inability to tie privacy-related decisions such as Griswold v. Connecticut, 381 U.S. 479 (1965), and Eisenstadt v. Baird, 405 U.S. 438 (1972), to the constitutional text again raises the spectre of substantive due process as epitomized by Lochner v. New York, 198 U.S. 45 (1905). One commentator makes a plausible case for viewing the Court's most recent foray into privacy, the abortion case, Roe v. Wade, 410 U.S. 113 (1973), as less justifiable than the thoroughly discredited Lochner decision. Ely, The Wages of Crying Wolf: A Comment on Roe v. Wade, 82 YALE L.J. 920, 937-43 (1973). See also Wellington, Common Law Rules and Constitutional Double Standards; Some Notes on Adjudication, 83 YALE L.J. 221, 272-311 (1973).

179. 17 U.S. (4 Wheat.) 316 (1819). 
tail these nonconstitutional rights extends to the courthouse steps. Congress' authority to curtail constitutional rights does not. Congress' broad power over the availability of judicial relief for nonconstitutional claims gives it room to promote efficiency without endangering federal court availability for constitutional rights. ${ }^{180}$ In addition to authorizing total exclusion of many cases, it permits Congress to relegate many nonconstitutional claims to administrative courts in lieu of full-fledged Article III tribunals. ${ }^{181}$

The result of the foregoing is to strike a middle ground between the extremes of a complete absence of lower federal court jurisdiction and complete vesting of the federal constitutional jurisdictional grant. The extremes can be rejected on practical ${ }^{182}$ as well as constitutional grounds. Important and difficult questions arise in attempting to stake out a rational middle ground that is consistent with modern conditions and with the Article III grant of jurisdiction. In seeking a solution difficult lines have to be drawn. The true substantive impact of a jurisdictional statute may not always be apparent. The line between efficiency motivated and substantive jurisdictional statutes may not always be clear. Difficult distinctions are of course not peculiar to the problem at hand. Some consolation may also be had from the severe difficulties that would necessarily follow from embracing an opposite view. If Congress may single out a class of cases for exclusion from lower federal courts because of disagreement with judicial results, there is no principled way to brake this power short of permitting removal of all constitutional issues from those courts.

\section{Remedies and Busing}

Yakus and other cases indicate that Congress must provide remedies for protecting rights. ${ }^{183}$ The power to regulate remedies, like the power to regulate jurisdiction, is sometimes translatable into a power to regulate substantive rights. ${ }^{184}$ Statutes that control jurisdiction to issue remedies can thus affect substantive rights. They are, therefore, subject to the same restrictions as jurisdictional statutes, which leads to the following conclusions analogous to those reached with respect to jurisdictional statutes: (1) Congress cannot withdraw

\footnotetext{
180. For example, any diversity case in which a constitutional right is not at stake could be excluded. Diversity jurisdiction is often criticized for misallocating federal judicial resources. See H. Friendiy, supra note 37, at 139-52.

181. See Glidden Co. v. Zdanok, 370 U.S. 530 (1962); Crowell v. Benson, 285 U.S. 22 (1932).

182. See H. FrIENDLY, supra note 37, at 6-14.

183. See pp. 531-32, infra.

184. See Hill, supra note 14. As the discussion of the Norris-LaGuardia Act showed, the line between "jurisdiction" and "jurisdiction to issue remedies" is unclear.
} 
jurisdiction to issue any constitutionally required remedy; ${ }^{185}$ and (2) Congress can withdraw jurisdiction to issue any remedy not so required.

The school busing issue can be used to illustrate the permissible breadth of congressional jurisdictional control over district court remedies. If busing is a constitutionally required remedy in a particular case, ${ }^{186}$ then removal of jurisdiction to issue a busing order is clearly unconstitutional. Were it not, Congress, under the pretense of regulating remedies, could achieve substantive results otherwise beyond its power. That state courts can hear busing requests subject to Supreme Court review is no substitute; Supreme Court review is too infrequent to guarantee vindication of federal rights.

If a particular remedy is not constitutionally required, different considerations control. Providing particular remedies when no single remedy is constitutionally necessary is not essential for the proper conduct of the business of the federal judiciary. As long as the federal rights involved in a case can be adequately vindicated in some manner, Congress may adjust the available remedies with impunity. ${ }^{187}$

The cases support Congress' power to choose among remedies. In the area of taxation, the Court had upheld provisions requiring protesting taxpayers to pay taxes first and litigate later, ${ }^{188}$ forbidding injunctions against collection of taxes, ${ }^{189}$ and requiring taxpayers to contest assessments before, rather than after, payment. ${ }^{100}$ Similarly, in Yakus the Court rejected petitioner's claim that statutory preclusion of injunctive relief was unconstitutional, ${ }^{191}$ and in 1868 , the Court

185. That there may be constitutionally required remedies is suggested by Swann v. Charlotte-Mecklenburg Bd. of Educ., 402 U.S. 1 (1971). See Hill, supra note 14, at 1149.

186. Swann v. Charlotte-Mecklenburg Bd. of Educ., 402 U.S. I (1971). Part III of the Swann decision confronts the question of remedies and implies that in certain circumstances a remedy or remedies might be constitutionally required. "Once a right and a violation have been shown, the scope of a district court's equitable powers to remedy past wrongs is broad, for breadth and flexibility are inherent in equitable remedies... As with any equity case, the nature of the violation determines the scope of the remedy." Id. at 15-16. The school authorities argued that "the equity powers of federal district courts have been limited by Title IV of the Civil Rights Act of 1964" which reads in pertinent part:

Nothing herein shall empower an official or court of the United States to issue any order seeking to achieve racial balance in any school by requiring the transportation of pupils or students from one school to another or one school district to another in order to achieve such racial balance, or otherwise enlarge the existing power of the court to insure compliance with constitutional standards.

Id. at 16-17. The Court interpreted this section to mean not that Congress was attempting to curtail existing equitable remedies, but that it wanted the courts to understand that it was not creating new remedies to attack de facto segregation. Id.

187. See Hart, supra note 102, at 1366-67.

188. See Phillips v. Commissioner, 283 U.S. 589 (1931); Springer v, United States, 102 U.S. 586 (1880).

189. See Snyder v. Marks, 109 U.S. 189 (1883).

190. See Cary v. Curtis, 44 U.S. (3 How.) 236 (1845).

191. 321 U.S. at $439-43$. 
upheld withdrawal of its habeas corpus appellate jurisdiction where a direct petition to it would lie and where lower federal courts still had jurisdiction to hear habeas petitions. ${ }^{192}$

\section{Conclusion}

The inability of the Supreme Court to do justice in every case within the Article III grant of jurisdiction has broad implications. It means that Congress cannot deny lower federal courts jurisdiction on the ground that Supreme Court review of state court decisions provides an adequate mechanism for vindicating federal rights. It also means that jurisdictional statutes which foreclose only lower federal court jurisdiction and which have substantive impact must be subjected to constitutional scrutiny. ${ }^{193}$ The conclusion is also inescapable that Congress cannot withdraw federal jurisdiction to hear cases in which constitutional rights are at stake; ${ }^{104}$ nor can Congress

192. Compare Ex parte McCardle, 74 U.S. (7 Wall.) 506 (1868), with Ex parte Yerger, 75 U.S. (8 Wall.) 85 (1868). See Note, supra note 12, at 1555-56. McCardle, which upheld Congress' power to withdraw the Supreme Court's appellate jurisdiction in habeas corpus cases, lends some support to those who feel Congress has substantial control over the Supreme Court's appellate jurisdiction under the "exceptions" clause. The case does not undercut the thesis advanced here because the jurisdictional withdrawal did not affect the power of lower federal courts to hear habeas corpus cases. Sec Fay v. Noia, 372 U.S. 391,406 n.15 (1963).

Yerger can perhaps be seen as lending substantial weight to the thesis advanced here. In Yerger the Court, in an opinion written by Chief Justice Chase, relied on a portion of the Judiciary Act of 1789 not repealed by the statute withdrawing the Supreme Court's appellate jurisdiction in habeas corpus cases (upheld in McCardlc) to assert jurisdiction to issue its own writ of habeas corpus. The Circuit Court for Mississippi had refused to issue the writ. If Chief Justice Chase's opinion is to be reconciled with his opinion in McCardle, where he also wrote for the majority, it must be read very narrowly. While it is true that $M c$ Cardle was decided on the basis of the exceptions clause, it is also true that in Yerger the Court was in fact serving as an appellate court for the order denying the writ. At one point, Chief Justice Chase wrote, "They [the words of the act] affected only appeals and appellate jurisdiction authorized by that act. They do not purport to touch the appellate jurisdiction conferred by the Constitution, or to except from it any cases not excepted by the act of 1789." Id. at 105 .

The essence of any narrow reading of Yerger must be that the Constitution explicitly grants the courts the right to issue a writ of habeas corpus. U.S. Cosst. art. 1, $\$ 9$, cl. 2. Even read in this light, the Yerger case puts a gloss on Article III, $\$ 2$, cl. 2, that generally supports the thesis advanced here.

193. Contrast with the conclusion reached here the statement:

Habeas corpus aside, I'd hesitate to say that Congress couldn't effect an unconstitutional withdrawal of jurisdiction-that is, a withdrawal to effectuate unconstitutional purposes-if it really wanted to.

Hart, supra note 102, at 1398-99. One interesting side-effect of this statement, if accepted, would be that, in effect, the Congress without the concurrence of the states could repeal the Tenth Amendment by a jurisdictional statute.

194. The conclusion that federal courts must be available to vindicate constitutional rights has important implications for federal habeas law. In Fay v. Noia, 372 U.S. 391 (1963), and Brown v. Allen, 344 U.S. 443 (1953), the two landmarks in the modern expansion of federal habeas corpus, the Court proceeded by construing the federal habeas statutes and by ascertaining the historical scope of the Great Writ. Some have argued that it misconstrued those statutes, see BAToR, supra note 11, at 1467 n.3; Mayers, The Habeas Corpus Act of 1867: The Supreme Court as Legal Historian, $33 \mathrm{U}$. CuI. L. Rev. 31 (1965), and that it misread the Writ's history. See Oaks, Legal History in 
withdraw jurisdiction to grant constitutionally required remedies.

Lest anyone misinterpret the argument advanced here, let me add one caveat that has been noted earlier. It is clear from the text of the Constitution and the Convention's deliberations that no single form of lower court system is mandated.195 It may well suffice to provide an appeal to a subordinate federal court from state courts, ${ }^{196}$ as long as such forums are generally available.

The lower federal courts are thus indispensable if the judiciary is to be a co-equal branch and if the "judicial Power of the United States" 197 is to remain the power to protect rights guaranteed by the Constitution and its Amendments. Abolition of the lower federal courts is no longer constitutionally permissible; with the demise of the assumption that they may be abolished it must necessarily follow that the jurisdiction of these courts is not a matter solely within the discretion of Congress. ${ }^{198}$

the High Court-Habeas Corpus, 64 MICH. L. REv. 451 (1966); Developments in the Lau-Federal Habeas Corpus, 83 HaRv. L. Rev. 1038, 1045-50 (1970).

Fay and Brown can be placed on alternative and more permanent footing by regarding federal habeas corpus for state prisoners not as a matter of statutory or historical interpretation, but merely as one necessary technique for implementing the national judiciary's role as vindicator of individual rights in each case within its jurisdiction. This is not to say that federal habeas is the only possible means of satisfying this role. Absent alternatives, widespread federal habeas for state prisoners may well be constitutionally mandated. Each state applicant need not be afforded a full-blown federal hearing. Reliance on the record of the state proceedings is not only appropriate, but probably necessary to avoid undue burdens on the lower courts. See LaVallec v. Delle Rose, 410 U.S. 690 (1973); Townsend v. Sain, 372 U.S. 293 (1963).

195. The inadvisability of fixing in the Constitution the precise structure of the federal system's lower echelons was noted long ago. 3 Ellior, supra note 39, at 517 (Pendleton at Virginia deliberations).

196. "I perceive at present no impediment to the establishment of an appeal from the State courts to the subordinate national tribunals; and many advantages attending the power of doing it may be imagined." THE FederalisT No. 82, at 495 (New Am. Lib. ed. 1961) (A. Hamilton). One recent proposal designed, in part, to relieve the caseload burden created by state prisoners who seek federal habeas corpus, recommends creation of a federal appellate court with direct review over state criminal proccedings. Haynsworth, A New Court to Improve The Administration of Justice, 59 A.B....J. 841 (1973). See also Friendly, Is Innocence Irrelevant? Collateral Attacks on Criminal Judgments, 38 U. CHI. L. REv. 142, 166.67 (1970).

197. U.S. Const. art. III, \$1.

198. Two arguments which seemingly stress "political" considerations and which have not hitherto received attention in this article support giving Congress broad power to withdraw cases from the jurisdiction of the federal courts. The first of these suggests that the "legitimacy" of judicial review is "enormously buttressed" by allowing Congress broad, and substantive, jurisdictional power. BATOR, supra note 11 , at 364 . The second argument is that Congress, which now needs the courts to enforce and interpret its statutes, would not in fact severely limit lower federal court jurisdiction. Wechsler, The Courls and the Constitution, 65 Couum. L. Rev. 1001, 1006-07 (1965).

With respect to the first argument, it scems to me that endangering the liberties of all of us is an excessively high price to pay for some unknown amount of legitimation of judicial review, a phenomenon not seriously under attack in this country. It would be small consolation to a black forced to use segregated public facilitics becatuse of a withdrawal of federal jurisdiction to know that his loss has in some mystical way strengthened the judiciary's authority to hold federal laws unconstitutional.

As for the second argument, it is comforting to think that, because of the exigencies of the day, it is unlikely that jurisdictional cutbacks will occur. The threat, however, is more real than Professor Wechsler Ieads us to believe, cspecially as the recent controversy about limiting federal court authority to issue busing orders amply illustrates. 